\title{
Geochemistry of skarn and porphyry deposits in relation to epithermal mineralization in the Arasbaran metallogenic zone, NE Tabriz, Iran
}

\author{
Ghafour ALAVI ${ }^{1, *}$, Kaikhosrov RADMARD² ${ }^{2}$ Hassan ZAMANIAN ${ }^{2}$, Mohammad Reza HOSSEINZADEH \\ and Ahmad Ahmadi KHALAJI ${ }^{2}$
}

1 University of Tabriz, Department of Earth Sciences, Faculty of Natural Sciences, Tabriz, Iran

2 Lorestan University, Department of Geology, Faculty of Natural Sciences, Khoram Abad, Iran

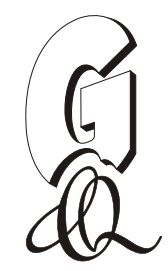

\begin{abstract}
Alavi, G., Radmard, K., Zamanian, H., Hosseinzadeh, M.R., Khalaji, A.A., 2020. Geochemistry of skarn and porphyry deposits in relation to epithermal mineralization in the Arasbaran metallogenic zone, NE Tabriz, Iran. Geological Quarterly, 64 (1): 141-164, doi: 10.7306/gq.1520

The Arasbaran metallogenic zone in northern Iran is part of the Alborz-Azerbaijan magmatic zone, which developed along the southern margin of Eurasia during the Early Mesozoic-Late Cenozoic. This region hosts precious and base metal mineralization, including porphyry, skarn, and epithermal copper, molybdenum, and gold deposits. Rare earth element variations across all the deposits are similar, indicating a similar source for these elements. The north-west trending belt comprising the Nabijan to the Sonajil deposits consistently shows chiefly alkaline conditions of formation. Fluid inclusion studies indicate that both high and low temperature hydrothermal fluids participated in the formation of all of the deposits. The mineralization age decreases from north to south and east to west and, although metal zonation is complex, the Cu-Au association post-dated the $\mathrm{Cu}-\mathrm{Mo}$ mineralization reflecting that the ore fluid evolved in terms of both cooling and chemical changes due to fluid-fluid and fluid-rock interactions. In this region most deposits record a concentric zonation, with the centres preserving porphyry and skarn deposits and deposits becoming progressively epithermal toward the outer parts of the mineralizing system. According to this, the mineralization age decreases from the porphyry and skarn deposits to the epithermal deposits. The homogenization temperature and salinity both decrease from the centre to the outer zone. The pattern of homogenization temperature zonation, which is concordant with salinity zonation, suggests that fluids migrated up-dip and towards the margins of the zonation system.
\end{abstract}

Key words: Arasbaran metallogenic zone, porphyry deposits, skarn deposits, epithermal deposits, fluid inclusions, Iran.

\section{INTRODUCTION}

The east-west trending Alborz Magmatic Belt (AMB) in northern Iran is divided into western and eastern parts. The western part, referred to here as the Alborz-Azarbaijan Magmatic Belt (AAMB), is subdivided into the Arasbaran metallogenic zone (AMZ) in the north and the Tarom-Hashtjin metallogenic province (THMP) in the south (Fig. 1; Azizi and Jahangiri, 2008; Azizi and Moinevaziri, 2009). The eastern part consists of basic and felsic tuffs and lavas with alkaline to shoshonitic affinities, whereas the western part consists of andesitic to dacitic lavas and many calc-alkaline to shoshonitic granitoid bodies (Radmard et al., 2019).

This region in the Tethyan realm is an important component of a regional metallogenic zone extending from the Pontide belt in Turkey to the Himalayas. Large Cu-Mo porphyry deposits, Cu-skarn occurrences (Mollai,1993) and Cu-Mo-Au epithermal-vein deposits (Radmard et al., 2019) in this area indicate

\footnotetext{
* Corresponding author, e-mail: gafouralavi346@gmail.com
}

Received: August 24, 2019; accepted: January 7, 2020; first published online: March 30, 2020 the economic value and potential of mineralization in this magmatic belt and hence requirement of more systematic studies of metallogenesis and resource exploration.

Epithermal, base metal and porphyry deposits in Iran are mainly related to magmatic belts, including the NW-SE trending Urmieh-Dokhtar and E-W-trending Alborz which are part of the Alpine-Himalayan orogenic system (Yang et al., 2009). The most important porphyry deposits in Iran include the (Fig. 1): Sungun (Calagari, 2003), Dali (Zarasvandi et al., 2015), Aliabad (Zarasvandi et al., 2005), Sarcheshmeh (Aftabi and Atapour, 2010), Meiduk (Aftabi et al., 2008) and Shadan (Karimpour et al., 2014) deposits. Some of the recognized epithermal Au deposits of Iran are located in the AMZ (Fig. 2): Masjeddaghi, Mazraeh-e-Shadi, Zaglic, Safikhanlo (Alirezaei et al., 2011).

Demonstrating the origin of hydrothermal fluids responsible for the formation of epithermal deposits is one of the essential steps in the study of this type of deposits, and the concentrations of rare earth elements (REEs), La to Lu in the hydrothermal fluids, may yield useful data regarding the origin of ore-forming elements including base metals (Kato, 1999). REEs behave coherently during most geological processes due to similar chemical and physical properties (e.g., Taylor and McLennan, 1985). In spite of this similarity, REEs can be fractionated during geochemical processes. Thus, REE patterns normalized to standard material have been widely used 


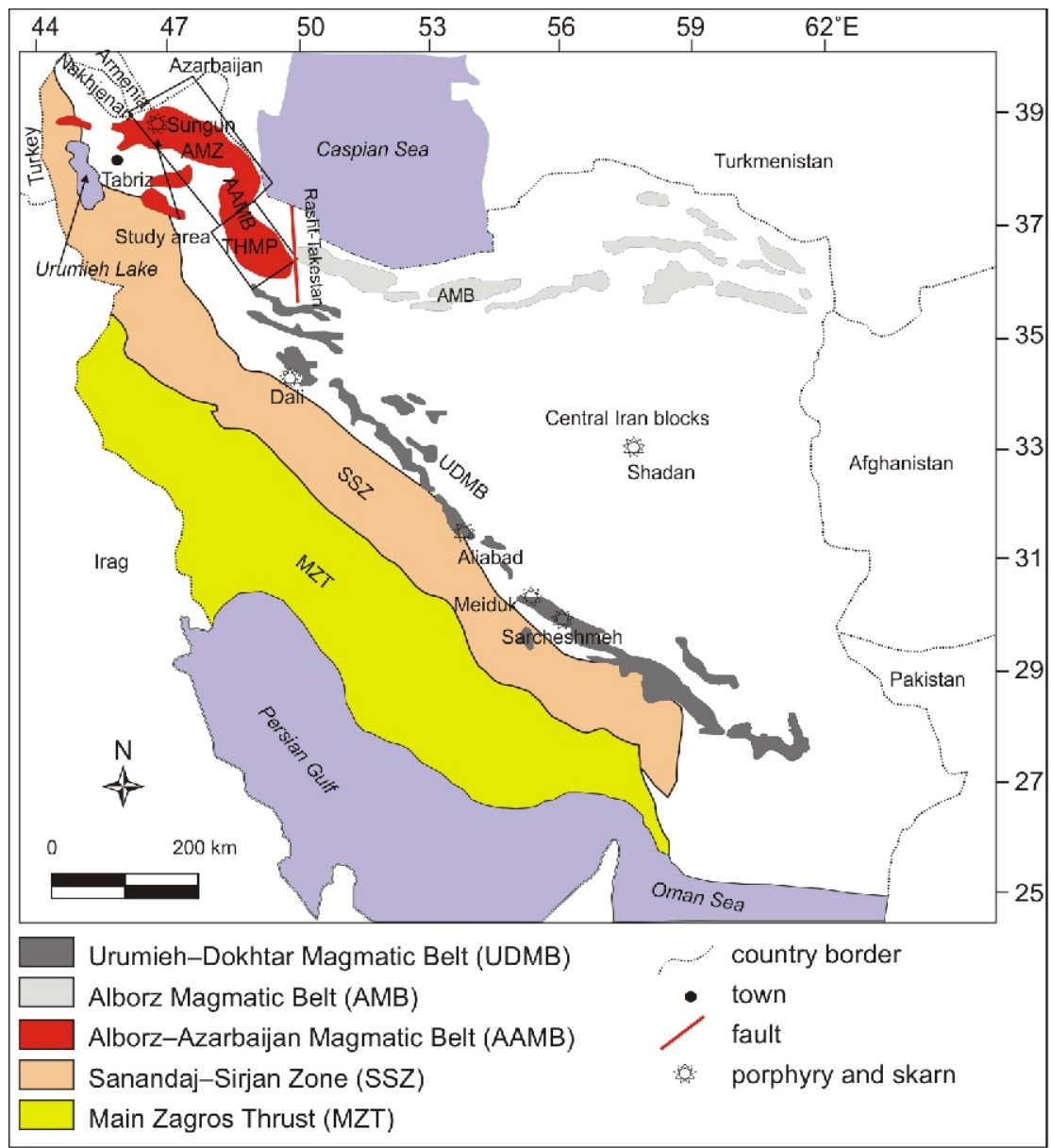

Fig. 1. A simplified geotectonic map of Iran (Nabavi, 1976) with location of the Arasbaran metallogenic zone (AMZ) encompassing the deposits studied

The Alborz-Azarbaijan Magmatic Belt (AAMB), is subdivided into the AMZ in the north and the Tarom-Hashtjin metallogenic province (THMP) in the south

as a tool to reveal various geochemical processes. However, there are only a few geochemical studies on REEs in the deposits located in the AMZ.

Fluid inclusions within hydrothermal veins have been recognized as records of mineralizing fluids and the processes by which mineral deposits were formed (Wilkinson, 2001). One of the essential aims of a fluid inclusion study is to establish a geochemical model through collecting data about the components and physico-chemistry of the palaeofluids (Williams-Jones and Heinrich, 2005). Fluid inclusion studies form an important tool for constraining the physico-chemical features of the hydrothermal fluids responsible for pervasive alteration and mineralization processes (Nash and Theodore, 1971; Nash, 1976; Batchelder, 1977; Chivas and Wilkins, 1977; Etminan, 1977; Roedder, 1984)

Studies on the mineralization in the AMZ have been limited and provide little insight into the origin of the deposits located in this zone (e.g., Mazraeh-e-Shadi, Safikhanlo, Sungun, Mazraeh, Anjerd, Masjeddaghi, Zaglic). In this paper, we describe the geological setting and geochemical characteristics of the deposits in the AMZ, including REEs and fluid inclusions, which help determine the relationships between the deposits and act as guidelines for future exploration in the AAMB. Our results extend knowledge of the epithermal mineralization processes in the $\mathrm{AAMB}$, and provide exploration criteria for similar epithermal ores in this area and in other parts of the AMB arc in northwestern Iran.

\section{GEOLOGICAL SETTING}

Regional tectonic setting. There are five major tectonic zones in northwestern Iran related to the geodynamic evolution of the Tethyan realm between the Arabian and Eurasian plates during the Early Mesozoic-Late Cenozoic. These zones include, from south to north, the Zagros Suture and Fold-Thrust Belt, the Sanandaj-Sirjan Zone (SSZ), the Urumieh-Dokhtar Magmatic Belt (UDMB), the Central Iran blocks, and the AAMB (Alavi, 1994), shown in Figure 1.

The UDMB represents a continental arc that formed as a result of the subduction of Neotethyan oceanic crust under the SSZ in the late Mesozoic (Alavi, 1994). North of the UDMB, discrete fragments of the Central Iran blocks crop out from beneath the Tertiary volcanic cover. Prior to the Triassic continental rifting episode, the Central Iran, South Armenian, and Tauride blocks formed a microcontinent that was a part of the northern edge of Gondwana (Sosson et al., 2005; Azizi and Moinevaziri, 2009; Mollai et al., 2009; Dilek et al., 2010). All three blocks include a Proterozoic crystalline basement overlain by Paleozoic-Mesozoic sedimentary sequences (Sosson 


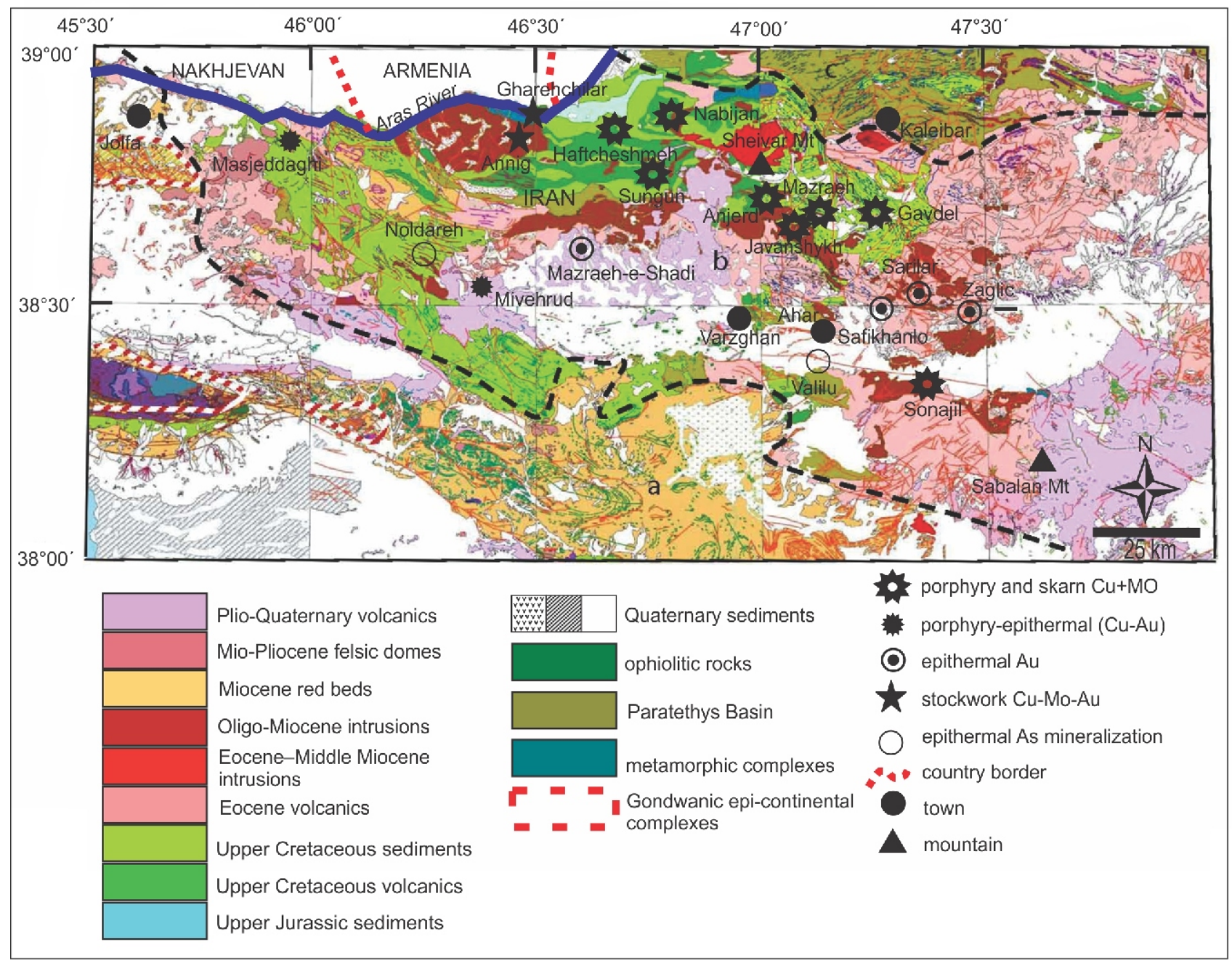

Fig. 2. Sketch geological map of the Arasbaran region with location of the deposits (compiled and modified from 1:100,000 geological map sheets of the GSI)

a - Central Iran Block with Cenozoic cover, b - AMZ, c - Paratethys sedimentary rocks; dashed line shows the limit of the structural units

et al., 2005; Dilek and Sandvol, 2009; Rolland et al., 2009). The $\mathrm{E}-\mathrm{W}$ trending Tertiary AMB in northern Iran is divided into western and eastern zones by the Rasht-Takestan Fault.

The calc-alkaline and shoshonitic magmatic activity in the UDMB started in the Eocene and continued into the Quaternary (Daliran and Neubaer, unpublished data). The youngest volcanic activity in the UDMB is mainly alkaline in nature and is associated with tectono-magmatic processes related to post-collisional, intra-continental rifting events (Richards, 2003). The south of the UDMB is dominated by basic to intermediate igneous rocks with calc-alkaline to alkaline affinities and host the Sarcheshmeh and Meiduk porphyry copper deposits (Fig. 1). No porphyry copper mineralization has yet been reported from the UDMB zone to the north.

The AMZ in the western zone is separated from the UDMB by a narrow fragment of the Central Iran microcontinent. To the north-west, the AAMB extends into the Lesser Caucasus in Armenia and into the Eastern Pontides in Turkey. The AMZ developed along the southern margin of Eurasia. Upper Jurassic-Cretaceous flysch deposits and platform carbonates deposited adjacent to this margin are overlain by Eocene volcanic rocks, and are intruded by Oligo-Miocene, shallow-crustal to hypabyssal plutons that collectively make up the AMZ (Fig. 2). A geological map of deposits in this region is shown in Figure 3.

Throughout the Paleogene and Neogene, the AMZ was bordered to the north and north-east by the Moghan basin, in which Eocene to Miocene clastic rocks accumulated, and in the south and south-west by a fluvio-lacustrine terrestrial basin, in which Miocene red beds including clastic sediments and evaporites were deposited. During the Late Miocene to Quaternary, the Lesser Caucasus and the AMZ underwent regional contraction, shortening first in a N-NW direction and subsequently in a NNE direction. The NNE-oriented crustal shortening was accompanied by WNW stretching and extension, and associated intensive alkaline magmatism in a broad zone of dextral transtension in the hinterland of the Arabia-Eurasia collision front (Mohajjel and Fergusson, 2000; Sosson et al., 2005; Dilek et al., 2010).

Regional geology. The magmatic rocks of the AMZ are high-K calc-alkaline to alkaline (Aghazadeh et al., 2011; Asiabanha and Foden, 2012; Castro et al., 2013; Nabatian et al., 2016), and are tectonically linked to subduction of the Neo-Tethys oceanic crust beneath the Iranian plate, and subsequent collision of Arabia with Eurasia during the Alpine-Hi- 


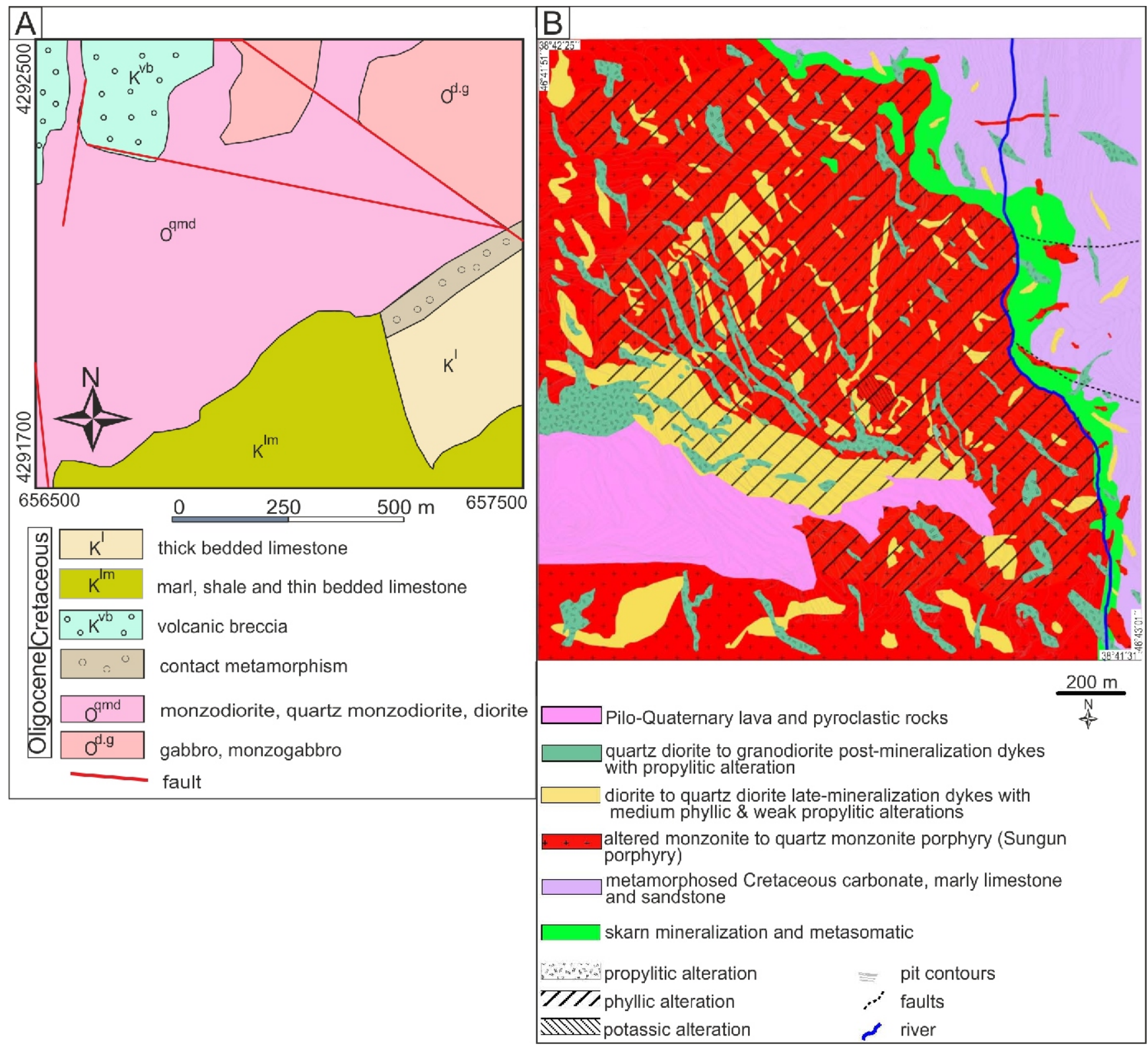

Fig. 3. Geological maps of deposits in the areas studied

A - Nabijan (Shokohi, 2007); B - Sungun (Aghazadeh et al., 2015)

malayan orogeny that caused the formation of different orogenic belts, including the AAMB, in which occur such deposits as the Mazraeh-e-Shadi, Sungun, Safikhanlo, Sarilar, and others (Alavi, 1994).

Cenozoic rocks of the $\mathrm{AMZ}$ on a $\mathrm{Na}_{2} \mathrm{O}+\mathrm{K}_{2} \mathrm{O}$ versus $\mathrm{SiO}_{2}$ discrimination diagram, can be compositionally classified as subalkaline basalt, andesite/basaltic andesite, and rhyodacite/dacite, and they plot mainly in the subalkaline field, though some of them fall into the alkaline field (Fig. 4).

Samples with 50 to $\sim 68 \mathrm{wt} . \% \mathrm{SiO}_{2}$ are calc-alkalic to alkalic (Fig. $5 \mathrm{~A}$ ), whereas samples with $>68$ wt. $\% \mathrm{SiO}_{2}$ are generally calcic (Frost et al., 2001); a limited subset of the volcanic rocks associated with the Mazraeh-e-Shadi deposit are particularly calcic. Cenozoic plutonic rocks of the $\mathrm{AMZ}$ are meta- to peraluminous (Fig. 5B).

On the $\mathrm{Rb}$ versus $\mathrm{Y}+\mathrm{Nb}$ tectonic discrimination diagram of Pearce et al. (1984), most of the igneous rocks associated with the deposits fall in the volcanic arc granite field, while some of the younger (Miocene) quartz-monzonitic and monzonitic plutons straddle the boundary with, and fall into the field of, within-plate granites (Fig. 6). On an $\mathrm{Nb}$ versus $\mathrm{Y}$ tectonic discrimination diagram, most of the igneous rocks are placed near the top of the volcanic arc granitoids (VAG field), but also span the compositional fields plotting in the third VAG, syn-COLG and WPG fields (Fig. 6).

Metallogenic belts. Mineralization and formation of ore deposits in orogenic belts commonly accompany igneous and associated hydrothermal activities (Sillitoe, 1997). Although some of this magmatism is related to active subduction zone processes as in volcanic arcs, the distribution and genesis of many important mineral deposits and occurrences in young orogenic systems appear to be spatially and temporally related to tectonic events that are either late in the collisional history or post-collisional in origin (Laffitte, 1984; Mitchell, 1996; Sillitoe, 


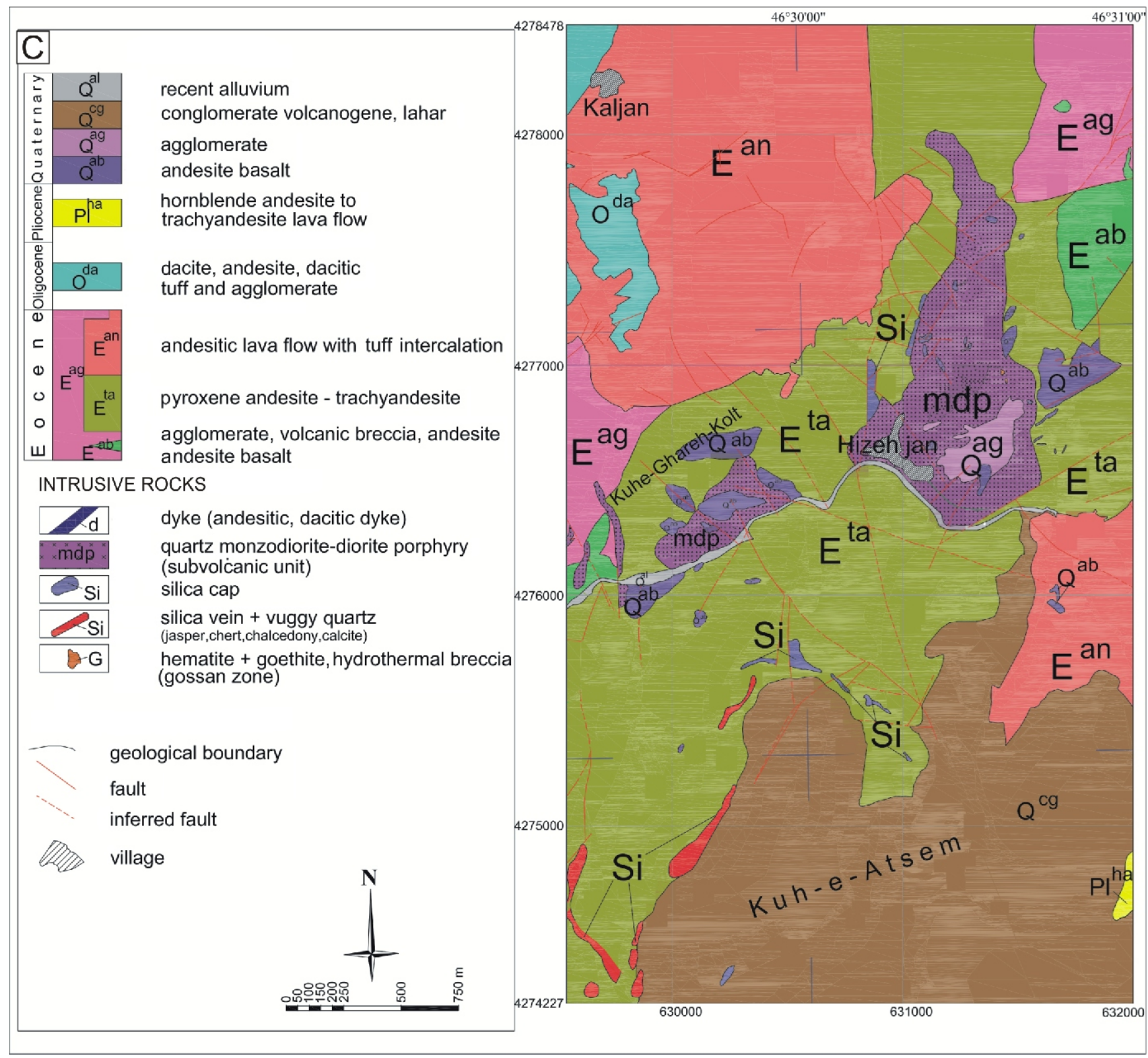

Fig. 3C - Mazraeh-e-Shadi (Radmard et al., 2017) 

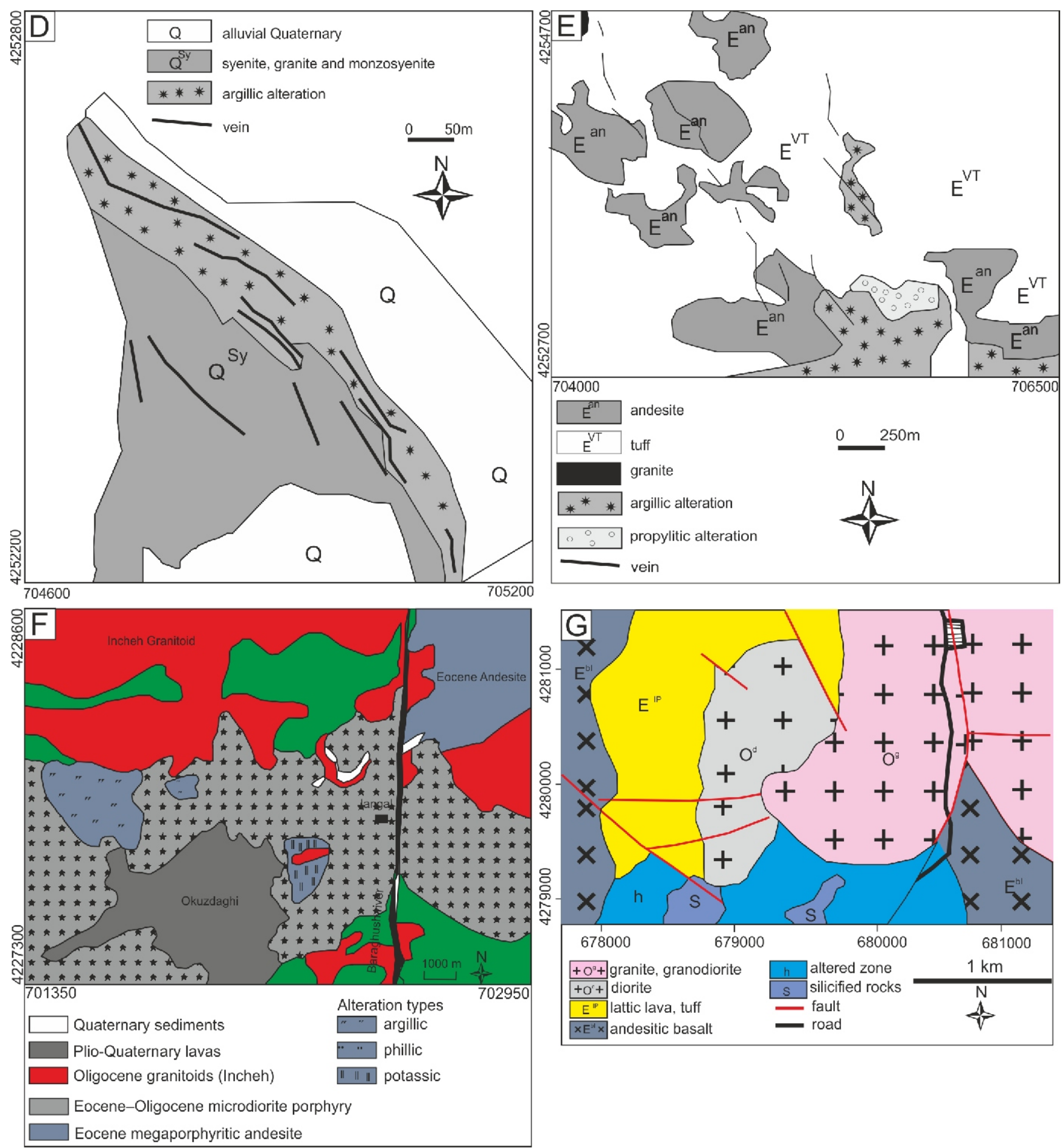

Fig. 3D, E - Safikhanlo and Zaglic (Alirezaei et al., 2011); F - Sonajil (Hosseinzadeh, 2008); G - Mazraeh (Mollai, 1993) 


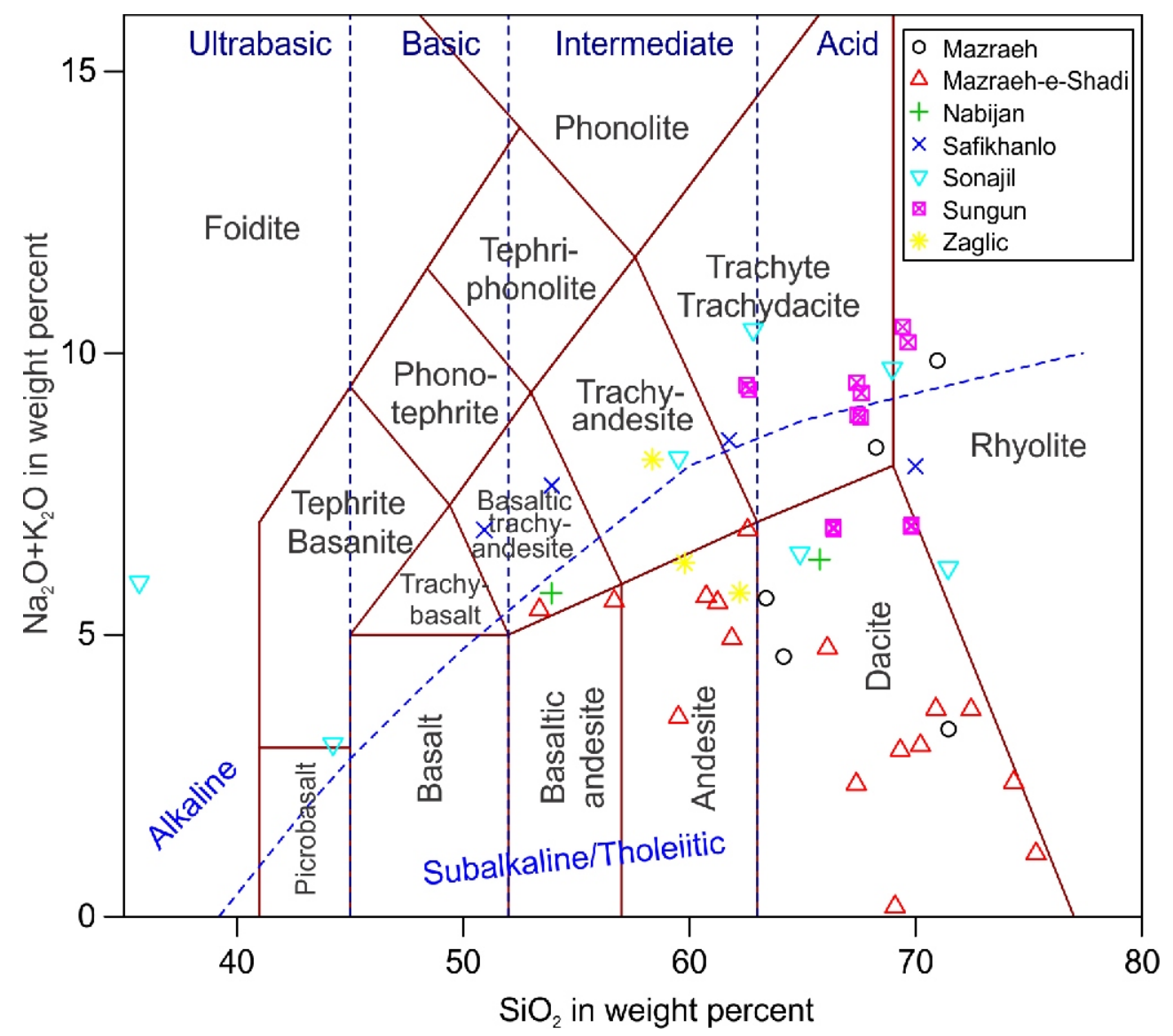

Fig. 4. Plots of representative rocks from the deposits on a total alkali vs. $\mathrm{SiO}_{2}$ diagram (Le Maitre, 2002)
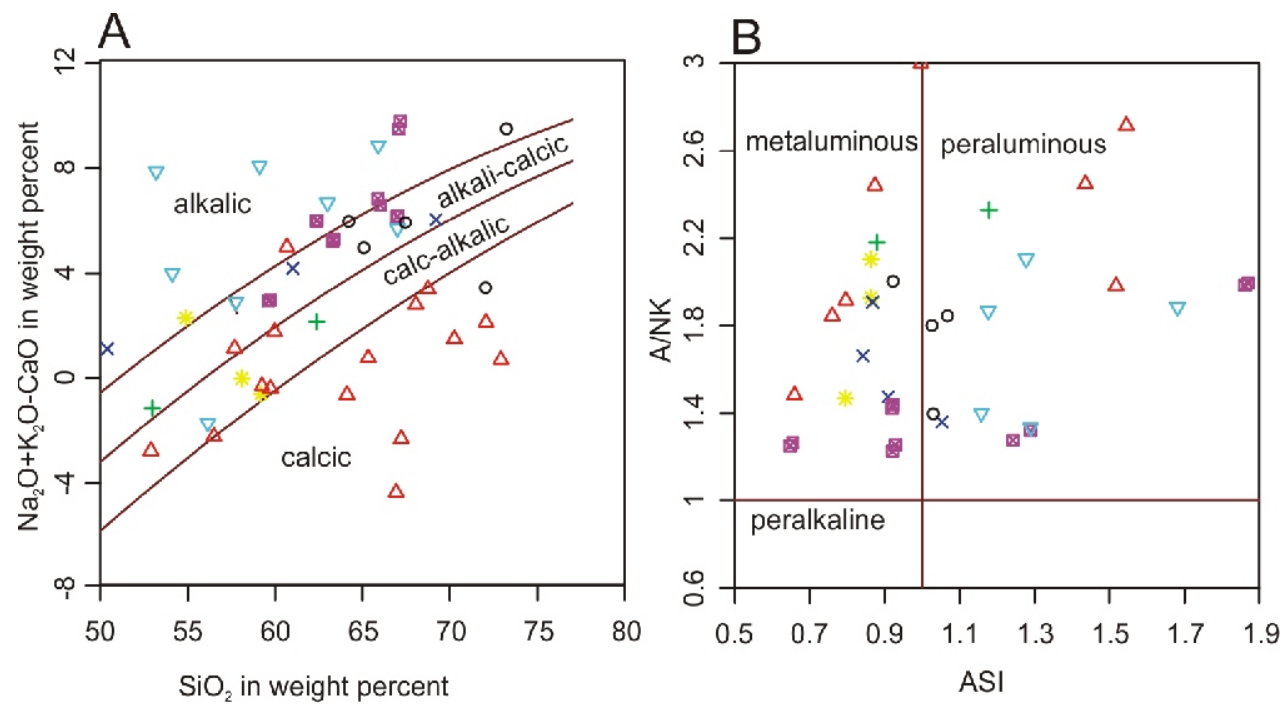

Fig. $5 \mathrm{~A}-\mathrm{Na}_{2} \mathrm{O}+\mathrm{K}_{2} \mathrm{O}-\mathrm{CaO}$ versus $\mathrm{SiO}_{2}$ diagram of igneous rocks associated with the deposits (Frost et al., 2001); B - a Shand's index diagram for the Arasbaran granitoids

Discrimination fields for different types of granitoids after Maniar and Piccoli (1989) and Shand (1927); symbols as in Figure 4 

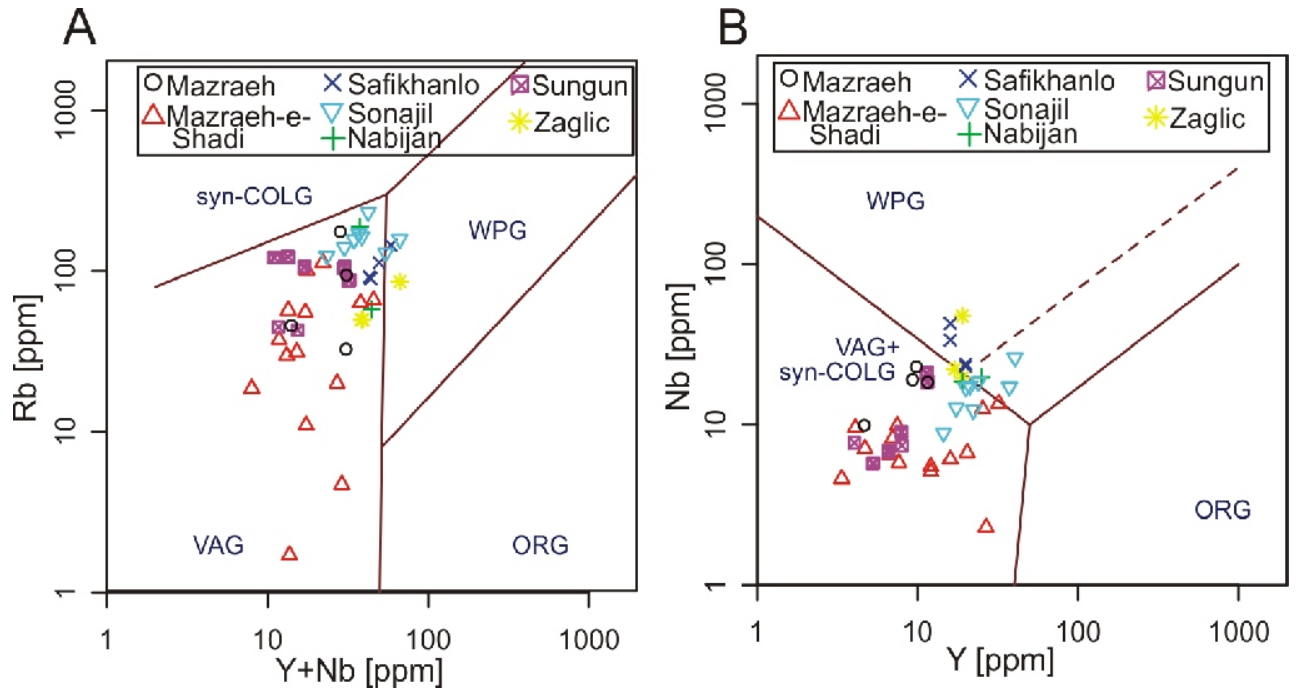

Fig. 6. Trace-element, tectonic setting-discrimination variation diagram showing the composition of igneous rocks associated with the deposits

A - Rb vs. (Yb+Nb); B - Nb vs. Y; VAG - volcanic arc granites, WPG - intra-plate granites, ORG ocean ridge granites, Syn-COLG - syn-collision granites; tectonic setting-composition boundaries after Pearce et al. (1984)

1997). The origin of heat flux, melt, and fluids, that collectively play a major role in metal transport and mineralization in post-collisional settings, raises fundamental questions in evaluating the relationships between metallogeny, magmatism, and regional tectonics in such orogenic systems.

The AMZ hosts precious and base metal mineralization, including copper, molybdenum, and gold within porphyry, skarn, and epithermal deposits (Tables 1 and 2). According to the distribution of the ore deposit types, three metallogenic zones are distinguished within the AMZ (Daliran et al., 2007), as shown in Figure 7:

b1. Zone A contains $\mathrm{Cu} \pm \mathrm{Mo} \pm$ Au porphyry and skarn deposits, and stockwork Cu-Mo-Au mineralization types.

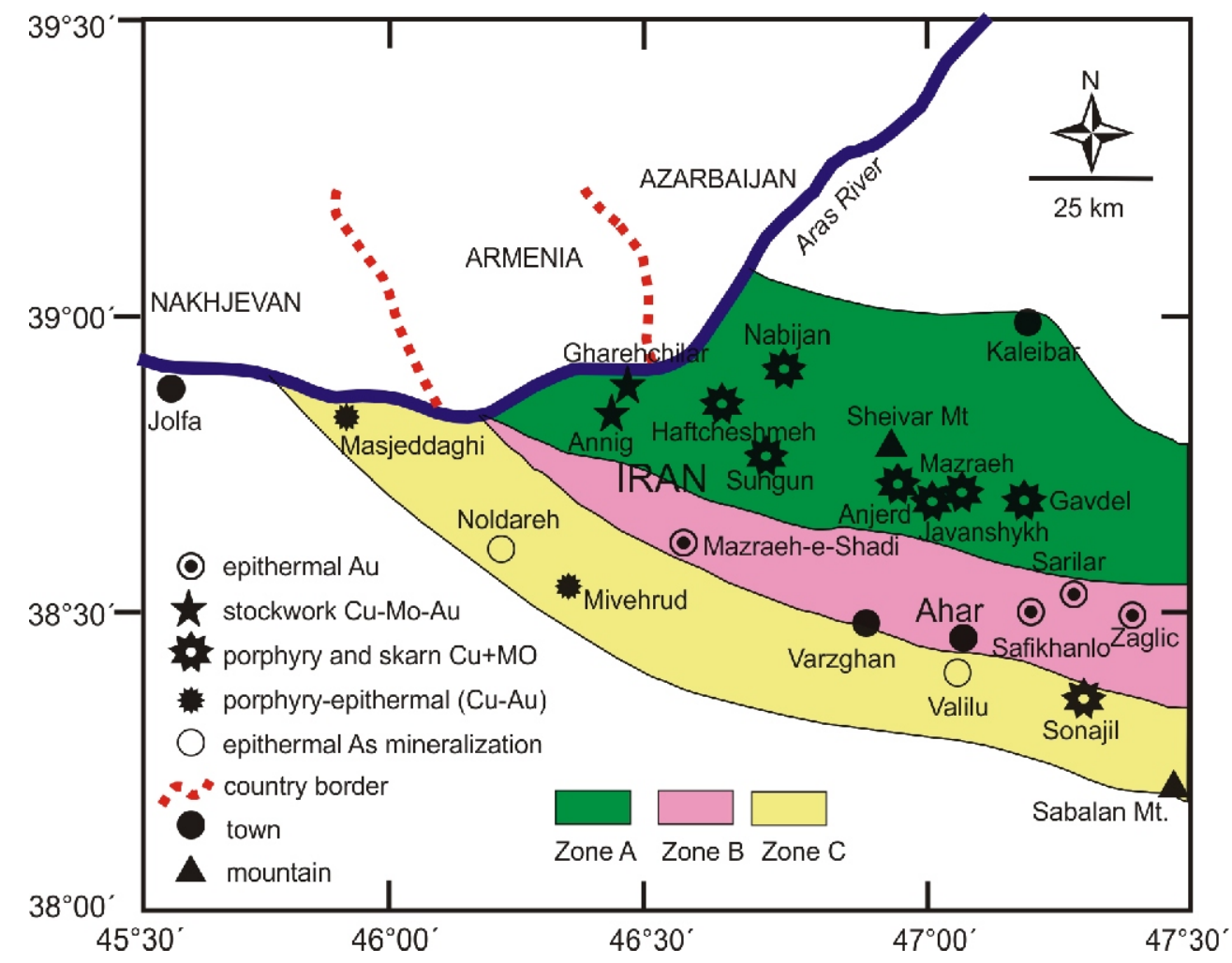

Fig. 7. Distribution of metallogenic zones and types of mineralization in the AMZ exposed in northwestern Iran (Jamalia et al., 2010) 
$\mathrm{T}$ a ble 1

Characteristics of the ore deposits associated with AMZ

\begin{tabular}{|c|c|c|c|c|c|c|c|c|}
\hline $\begin{array}{l}\text { Metal- } \\
\text { logenic } \\
\text { zone }\end{array}$ & Deposit & Location & Metals & $\begin{array}{l}\text { Magmatism/ } \\
\text { mineraliza- } \\
\text { tion age } \\
\text { [Ma] }\end{array}$ & $\begin{array}{l}\text { Mineraliza- } \\
\text { tion type }\end{array}$ & $\begin{array}{c}\text { Geology host/country } \\
\text { rocks }\end{array}$ & $\begin{array}{l}\text { Economic } \\
\text { potential }\end{array}$ & References \\
\hline \multirow{8}{*}{ A } & Sungun & $\begin{array}{l}38^{\circ} 41^{\prime} 53^{\prime \prime} \mathrm{N} \\
46^{\circ} 42^{\prime} 21^{\prime \prime} \mathrm{E}\end{array}$ & Cu-Mo & $\begin{array}{l}22.9 \pm 0.2 \\
\text { and } 21.7 \\
\pm 0.2 \mathrm{Ma}\end{array}$ & $\begin{array}{l}\text { porphyry, } \\
\text { skarn }\end{array}$ & $\begin{array}{l}\text { U. Cretaceous limestone } \\
\text { intruded by } \\
\text { granodiorite-monzodiorite } \\
\text { plutons }\end{array}$ & $\begin{array}{l}800 \mathrm{Mt} \text { at } \\
0.6 \% \mathrm{Cu} ; \\
\text { open pit } \\
\text { mining }\end{array}$ & $\begin{array}{l}\text { Simmonds et al. } \\
(2017)\end{array}$ \\
\hline & Nabijan & $\begin{array}{l}38^{\circ} 45^{\prime} 58^{\prime \prime} \mathrm{N} \\
46^{\circ} 48^{\prime} 24^{\prime \prime} \mathrm{E}\end{array}$ & $\mathrm{Cu}-\mathrm{Au}$ & $\begin{array}{l}\text { U. Eocene } \\
\text { to } \\
\text { Oligocene }\end{array}$ & $\begin{array}{l}\text { porphyry, } \\
\text { skarn }\end{array}$ & $\begin{array}{l}\text { U. Cretaceous } \\
\text { volcano-sedimentary } \\
\text { rocks intruded by } \\
\text { monzonitic plutons }\end{array}$ & $\begin{array}{l}0.4 \mathrm{ppm} \mathrm{Au} \\
0.1 \% \mathrm{Cu}\end{array}$ & $\begin{array}{l}\text { Baniadam (2002), } \\
\text { Shokohi (2007) }\end{array}$ \\
\hline & Anjerd & $\begin{array}{l}38^{\circ} 39^{\prime} 17^{\prime \prime} \mathrm{N} \\
47^{\circ} 03^{\prime} 53^{\prime \prime} \mathrm{E}\end{array}$ & $\mathrm{Cu}-(\mathrm{Fe})$ & Miocene & skarn & $\begin{array}{l}\text { U. Cretaceous } \\
\text { volcano-sedimentary } \\
\text { rocks intruded by the } \\
\text { Sheivar granodiorite- } \\
\text { monzonite pluton }\end{array}$ & $\begin{array}{c}400,000 \mathrm{t} \text { at } \\
1.5 \% \mathrm{Cu}\end{array}$ & $\begin{array}{c}\text { Mollai (1993), Mollai } \\
\text { et al.(2009), Atalu } \\
\text { (2006) }\end{array}$ \\
\hline & Mazraeh & $\begin{array}{l}38^{\circ} 39^{\prime} 17^{\prime \prime} \mathrm{N} \\
47^{\circ} 03^{\prime} 53^{\prime \prime} \mathrm{E}\end{array}$ & $\mathrm{Cu} \pm \mathrm{Au}$ & $10 \mathrm{Ma}$ & skarn & $\begin{array}{c}\text { U. Cretaceous } \\
\text { volcano-sedimentary } \\
\text { rocks intruded by the } \\
\text { Sheivar granodiorite- } \\
\text { monzonite pluton }\end{array}$ & $\begin{array}{c}400,000 \mathrm{t} \text { at } \\
1.5 \% \mathrm{Cu}\end{array}$ & Hassanpour (2010) \\
\hline & $\begin{array}{l}\text { Haftches } \\
\text { hmeh }\end{array}$ & $\begin{array}{l}38^{\circ} 45^{\prime} 42^{\prime \prime} \mathrm{N} \\
46^{\circ} 39^{\prime} 13^{\prime \prime} \mathrm{E}\end{array}$ & Cu-Mo & $\begin{array}{c}27.05 \pm 0.37 \\
\mathrm{Ma}\end{array}$ & porphyry & $\begin{array}{l}\text { U. Cretaceous limestone } \\
\text { intruded by granodiorite- } \\
\text { monzodiorite plutons }\end{array}$ & & $\begin{array}{c}\text { Aghazadeh et al. } \\
\qquad(2015)\end{array}$ \\
\hline & Anniq & $\begin{array}{l}38^{\circ} 49^{\prime} 08^{\prime \prime} \mathrm{N} \\
46^{\circ} 22^{\prime} 13^{\prime \prime} \mathrm{E}\end{array}$ & Cu-Mo-Au & L. Miocene & $\begin{array}{l}\text { stockwork, } \\
\text { intrusion- } \\
\text { related, } \\
\text { porphyry }\end{array}$ & $\begin{array}{c}\text { medium- to high-K, } \\
\text { calc-alkaline granodiorite, } \\
\text { monzonite and } \\
\text { diorite-gabbro plutons }\end{array}$ & $\begin{array}{l}1-2 \% \text { Mo; } \\
2 \text { ppm Au; } \\
\text { open pit } \\
\text { mining }\end{array}$ & $\begin{array}{l}\text { Jamali and Mehrabi } \\
(2015)\end{array}$ \\
\hline & Gharehchilar & $\begin{array}{l}38^{\circ} 50^{\prime} 49^{\prime \prime} \mathrm{N} \\
46^{\circ} 22^{\prime} 13^{\prime \prime} \mathrm{E}\end{array}$ & $\mathrm{Cu}-\mathrm{Mo}-\mathrm{Au}$ & $\begin{array}{l}25.19 \pm 0.19 \\
\text { to } 31.22 \\
\pm 0.28 \mathrm{Ma}\end{array}$ & $\begin{array}{l}\text { stockwork, } \\
\text { intrusion- } \\
\text { related, } \\
\text { porphyry }\end{array}$ & $\begin{array}{c}\text { medium- to high-K, } \\
\text { calc-alkaline granodiorite, } \\
\text { monzonite and } \\
\text { diorite-gabbro plutons }\end{array}$ & & $\begin{array}{l}\text { Simmonds and } \\
\text { Moazzen (2015) }\end{array}$ \\
\hline & Gavdel & $\begin{array}{l}38^{\circ} 40^{\prime} 30^{\prime \prime} \mathrm{N} \\
46^{\circ} 54^{\prime} 30^{\prime \prime} \mathrm{E}\end{array}$ & Cu-Mo-Au & Oligocene & skarn & & & Mollai (1993), Atalu \\
\hline \multirow{4}{*}{ B } & $\begin{array}{l}\text { Mazraeh-e- } \\
\text { Shadi }\end{array}$ & $\begin{array}{l}38^{\circ} 36^{\prime} 35^{\prime \prime} \mathrm{N} \\
46^{\circ} 29^{\prime} 20^{\prime \prime} \mathrm{E}\end{array}$ & $\mathrm{Au}$ & Miocene & $\begin{array}{l}\text { medium } \\
\text { sulphidation } \\
\text { epithermal }\end{array}$ & $\begin{array}{l}\text { U. Eocene dacitic rocks } \\
\text { intruded by dioritic dikes }\end{array}$ & $\begin{array}{l}6 \text { ppm Au; in } \\
\text { exploration }\end{array}$ & $\begin{array}{l}\text { Jamali and Mehrabi } \\
(2015)\end{array}$ \\
\hline & Sarilar & $\begin{array}{l}38^{\circ} 27^{\prime} 14^{\prime \prime} \mathrm{N} \\
47^{\circ} 19^{\prime} 59^{\prime \prime} \mathrm{E}\end{array}$ & $\mathrm{Au}$ & Oligocene & $\begin{array}{c}\text { low- } \\
\text { sulphidation } \\
\text { epithermal }\end{array}$ & $\begin{array}{l}\text { Eocene dacitic and } \\
\text { andesitic rocks intruded } \\
\text { by calc-alkaline plutons }\end{array}$ & $\begin{array}{c}1-10 \mathrm{ppm} \\
\text { Au; in } \\
\text { prospection }\end{array}$ & $\begin{array}{c}\text { Ghadimzadeh } \\
\text { (2002), Heidarzadeh } \\
(2006)\end{array}$ \\
\hline & Zaglic & $\begin{array}{l}38^{\circ} 26^{\prime} 44^{\prime \prime} \mathrm{N} \\
47^{\circ} 21^{\prime} 06^{\prime \prime} \mathrm{E}\end{array}$ & $\mathrm{Au}$ & Oligocene & $\begin{array}{l}\text { low- } \\
\text { sulphidation } \\
\text { epithermal }\end{array}$ & $\begin{array}{c}\text { Eocene dacitic and } \\
\text { andesitic rocks intruded } \\
\text { by calc-alkaline plutons }\end{array}$ & $\begin{array}{c}1-10 \text { ppm } \\
\text { Au; in } \\
\text { prospection }\end{array}$ & $\begin{array}{l}\text { Jamali and Mehrabi } \\
(2015)\end{array}$ \\
\hline & Safikhanlo & $\begin{array}{l}38^{\circ} 23^{\prime} 30 " \mathrm{~N} \\
47^{\circ} 19^{\prime} 56^{\prime \prime} \mathrm{E}\end{array}$ & $\mathrm{Au}$ & Oligocene & $\begin{array}{c}\text { low- } \\
\text { sulphidation } \\
\text { epithermal }\end{array}$ & $\begin{array}{c}\text { Eocene dacitic and } \\
\text { andesitic rocks intruded } \\
\text { by calc-alkaline plutons }\end{array}$ & $\begin{array}{c}1-10 \mathrm{ppm} \\
\text { Au; in } \\
\text { prospection }\end{array}$ & $\begin{array}{c}\text { Jamali and Mehrabi } \\
(2015)\end{array}$ \\
\hline \multirow{5}{*}{ C } & Sonajil & $\begin{array}{l}38^{\circ} 11^{\prime} 34^{\prime \prime N} \\
47^{\circ} 16 \text { '49"E }\end{array}$ & $\mathrm{Cu} \pm \mathrm{Au}$ & Oligocene & porphyry & $\begin{array}{c}\text { Middle to u. Eocene } \\
\text { andesiticrocks intruded by } \\
\text { medium- to high-K, } \\
\text { calc-alkaline subvolcanic } \\
\text { rocks }\end{array}$ & $\begin{array}{l}0.2 \% \mathrm{Cu} \text {; in } \\
\text { prospection }\end{array}$ & $\begin{array}{l}\text { Jamali and Mehrabi } \\
\qquad(2015)\end{array}$ \\
\hline & Valilu & $\begin{array}{l}38^{\circ} 20^{\prime} 36^{\prime \prime} \mathrm{N} \\
46^{\circ} 52^{\prime} 33^{\prime \prime} \mathrm{E}\end{array}$ & As & $\begin{array}{l}\text { Miocene- } \\
\text { Pliocene }\end{array}$ & epithermal & Miocene & $\begin{array}{l}\text { Abandoned } \\
\text { mine }\end{array}$ & $\begin{array}{l}\text { Jamali and Mehrabi } \\
(2015)\end{array}$ \\
\hline & Mivehrud & $\begin{array}{l}38^{\circ} 32^{\prime} 59^{\prime \prime} \mathrm{N} \\
46^{\circ} 15^{\prime} 31^{\prime \prime} \mathrm{E}\end{array}$ & $\mathrm{Cu}-\mathrm{Au}$ & $\begin{array}{c}9.12 \pm 0.19 \\
\mathrm{Ma}\end{array}$ & $\begin{array}{l}\text { porphyry, } \\
\text { epithermal }\end{array}$ & $\begin{array}{l}\text { U. Cretaceous to Palaeo- } \\
\text { cene flysch deposits in- } \\
\text { truded by medium- to } \\
\text { high-K, calcalkaline } \\
\text { subvolcanic rocks }\end{array}$ & $\begin{array}{l}1 \mathrm{ppm} \mathrm{Au}, \\
0.1 \% \mathrm{Cu}, \mathrm{low} \\
\text { grade; } 3 \mathrm{ppm} \\
\mathrm{Au}, \mathrm{Sb} \text { in } \\
\text { veins; in } \\
\text { prospection }\end{array}$ & $\begin{array}{c}\text { Alirezaei et al. } \\
(2016)\end{array}$ \\
\hline & Noldareh & $\begin{array}{l}38^{\circ} 47^{\prime} 23^{\prime \prime} \mathrm{N} \\
46^{\circ} 03^{\prime} 10^{\prime \prime} \mathrm{E}\end{array}$ & As & $\begin{array}{l}\text { Miocene- } \\
\text { Pliocene }\end{array}$ & epithermal & Miocene & $\begin{array}{l}\text { Abandoned } \\
\text { mine }\end{array}$ & $\begin{array}{c}\text { Jamali and Mehrabi } \\
(2015)\end{array}$ \\
\hline & Masjeddaghi & $\begin{array}{l}38^{\circ} 52^{\prime} 38^{\prime \prime} \mathrm{N} \\
46^{\circ} 56^{\prime} 19^{\prime \prime} \mathrm{E}\end{array}$ & $\mathrm{Cu}-\mathrm{Au}$ & $\begin{array}{c}20.46 \pm 3.55 \\
M a\end{array}$ & $\begin{array}{l}\text { porphyry, } \\
\text { high- } \\
\text { sulphidation } \\
\text { epithermal }\end{array}$ & $\begin{array}{l}\text { Eocene andesitic rocks } \\
\text { intruded by calc-alkaline } \\
\text { subvolcanic rocks }\end{array}$ & $\begin{array}{c}0.33 \% \mathrm{Cu}, 2 \\
\text { ppm Au }\end{array}$ & $\begin{array}{c}\text { Agahzadeh et al. } \\
(2015)\end{array}$ \\
\hline
\end{tabular}


Table 2

Characteristics of the fluids forming ore deposits studied in the AMZ

\begin{tabular}{|l|c|c|}
\hline \multicolumn{1}{|c|}{ Deposit name } & $\begin{array}{c}\text { Homogenization } \\
\text { temperature }\left[{ }^{\circ} \mathrm{C}\right]\end{array}$ & $\begin{array}{c}\text { Salinity (wt.\% } \mathrm{NaCl} \\
\text { equivalent) }\end{array}$ \\
\hline Sungun & 336.35 & 31.47 \\
\hline Sonajil & 400.25 & 22.96 \\
\hline Mazraeh & 356.11 & 23.92 \\
\hline Nabijan & 195 & 5.7 \\
\hline Mazraeh-e-Shadi & 227.94 & 1.94 \\
\hline Zaglic & 200.9 & 4.47 \\
\hline Safikhanlo & 267.5 & 1.77 \\
\hline Anjerd & 356.11 & 23.92 \\
\hline
\end{tabular}

The Sungun, Haftcheshmeh, Nabijan, and Mazraeh mines are located in this zone (Fig. 7).

2. Zone B comprises several epithermal gold deposits and occurrences (Zaglic, Safikhanlo, Sarilar, and Mazraeh-e-Shadi mines) (Fig. 7). Prominent examples of this type of mineralization are hosted by Eocene volcanic rocks.

3. Zone $\mathrm{C}$ contains deposits occurring in the mountain range from the Sabalan volcano in the south-east to the Jolfa region in the north-west. The main examples include the Mivehrud, Masjeddaghi, and Sonajil deposits.

Widespread, WNW-trending alteration zones that are parallel to the regional faults occur mainly within Eocene volcanic rocks in Zone B. Considering the alteration assemblages, vein minerals, and fluid inclusion data, Ebrahimi et al. (2009) recognised various types of epithermal system in the AMZ, as follows (Fig. 2): (1) low-sulphidation (Safikhanlo and Zaglic); (2) intermediate (e.g. Mazraeh-e-Shadi); (3) high-sulphidation (e.g. Masjeddaghi).

\section{METHODS}

In the present study, numerous field samples were taken and selected for different purposes. Polished and thin sections were studied by optical microscopy at Tabriz University. Most samples were taken from across the skarn, host rocks and quartz-sulfide breccia veins (related to epithermal deposits). Quantitative values of major and minor elements, trace elements, and REEs were determined by inductively coupled plasma-atomic emission spectrometry and inductively coupled plasma-mass spectrometry analysing methods (ICP-MS) in the Amdel Mineral Laboratory, Australia. Approximate detection limits for the elements are: $\mathrm{Au}=0.005 \mathrm{ppm}, \mathrm{Ag}=0.2 \mathrm{ppm}, \mathrm{Pb}$, $\mathrm{Zn}$ and $\mathrm{Cu}=0.5 \mathrm{ppm}$. Microthermometric studies were conducted on 100-150 $\mu$ m-thick polished slabs of quartz from silicified and mineralized zones. Sub-surface samples containing quartz veinlets obtained from diamond drill holes and surface samples were selected for thermometric analyses. Microthermometric studies were carried out at the Lorestan University Geological Department-Fluid Inclusion Laboratory using a Linkam THMSG600 freezing-heating stage mounted on an Olympus microscope. The freezing-heating stage has temperature range that varies from $-196-600^{\circ} \mathrm{C}$. Calibrations were performed using caesium nitrate (melting point of $+414^{\circ} \mathrm{C}$ ), $\mathrm{n}$-hexane (freezing point of $1-94.3^{\circ} \mathrm{C}$ ) and synthetic fluid inclusion standards. The heating rate was $5-10^{\circ} \mathrm{C} / \mathrm{min}$ at higher temperatures $\left(>100^{\circ} \mathrm{C}\right)$, with a reproducibility of $\pm 1^{\circ} \mathrm{C}$, but was reduced to $0.1-0.5^{\circ} \mathrm{C} / \mathrm{min}$ near phase transformation, with a reproducibility of $\pm 0.1^{\circ} \mathrm{C}$. Salinities of liquid-rich fluid inclusions were calculated from measured ice-melting temperatures using the equation of Bodnar (1993). Interpolation of data and creation of longitudinal sections for the veins was done using the Kriging interpolation function built in the Surfer software, version 9, Excel, Auto CAD, Fluids (Bakker, 1999), Clathrates (Bakker, 1997) and Flincore (Brown, 1989). The basic statistics, minimum, maximum, mean and standard deviation were calculated for every vein by SPSS software, version 16 .

\section{PORPHYRY DEPOSITS}

Sungun. The largest known porphyry Cu-Mo deposit in north-west Iran is the Sungun porphyry copper deposit (PCD), which is also the second largest PCD in Iran (after Sarcheshmeh PCD). The Sungun deposit, located in the NW part of Iran $\sim 100 \mathrm{~km} \mathrm{NE}$ of Tabriz, the most prominent porphyry $\mathrm{Cu}-\mathrm{Mo}$ in Zone A with ore reserves of $\sim 796 \mathrm{Mt}$ at $0.6 \% \mathrm{Cu}$, and probable reserves $>1 \mathrm{Gt}$ (Simmonds and Moazzen, 2015), has been mined within the enriched, sericitic shallow mineralization zone.

The Sungun mineralization, represented by a chalcopyrite-pyrite-bornite assemblage, is associated with Oligo-Miocene granodiorite-monzonite and diorite-granodiorite plutons (Hezarkhani, 2006). The parental magma of these plutons was medium- to high-K calc-alkaline in composition and was emplaced into the country rock at shallow crustal depths of $2 \mathrm{~km}$ and at temperatures of $\sim 670-780^{\circ} \mathrm{C}$ (Hezarkhani, 2006). The existence of primary hornblende in the fresh diorite-granodiorite rocks suggests that the parental magma was hydrous. It is inferred that the exsolution of fluids from wet magma at shallow depths during the early crystallization stage of the stocks and plutons caused the precipitation of Mo and $\mathrm{Cu}$ minerals in the intrusions (Hezarkhani and Williams-Jones, 1998).

Four alteration types are developed in Sungun deposit: potassic, phyllic, propylitic and argillic. The earliest alteration is represented by potassic mineral assemblages (dominated by $\mathrm{K}$ feldspar) developed pervasively and as halos around veins in the deep and central parts of the Sungun stock (Hezarkhani and Williams-Jones, 1998). The potassic alteration displays a close spatial association with copper and molybdenum mineralization; as much as $60 \%$ of the copper and all of the molybdenum was possibly emplaced during this alteration episode (Hezarkhani and Williams-Jones, 1998). Three types of fluid inclusion are typically observed in quartz veinlets at Sungun: (1) vapour-rich, two-phase, (2) liquid-rich two-phase (Fig. 8A) and (3) multi-phase. However, occasionally mono-phase solid (minute halite crystal) inclusions are also observed in some samples. Multi-phase inclusions include those containing liquid, vapour, and solid phases. There may be only one (principally halite) or several solid phases (e.g., halite, sylvite, and an unknown transparent solid). The homogenization temperature varies between $192-584^{\circ} \mathrm{C}$ and salinity varies between $1-68 \mathrm{wt} . \% \mathrm{NaCl}$ equivalents. The microthermometric data and calculated parameters such as salinities, homogenization temperatures and salinities vs. homogenization temperatures binary diagram for all deposits is graphically illustrated in Figure 9.

Sonajil. Rocks of the Sonajil region include Eocene andesite lava, porphyry microdiorite, Incheh granitoid and Ozuzdaghi Plio-Quaternary volcanic rocks. Porphyry microdiorite is the main host rock of porphyry type Cu-Mo mineralization in the Sonajil. Activity of hydrothermal fluids caused formation of sulphide, sulphosalt and oxide (magnetite, hematite) minerals in the form of dissemination, veins and veinlets. 

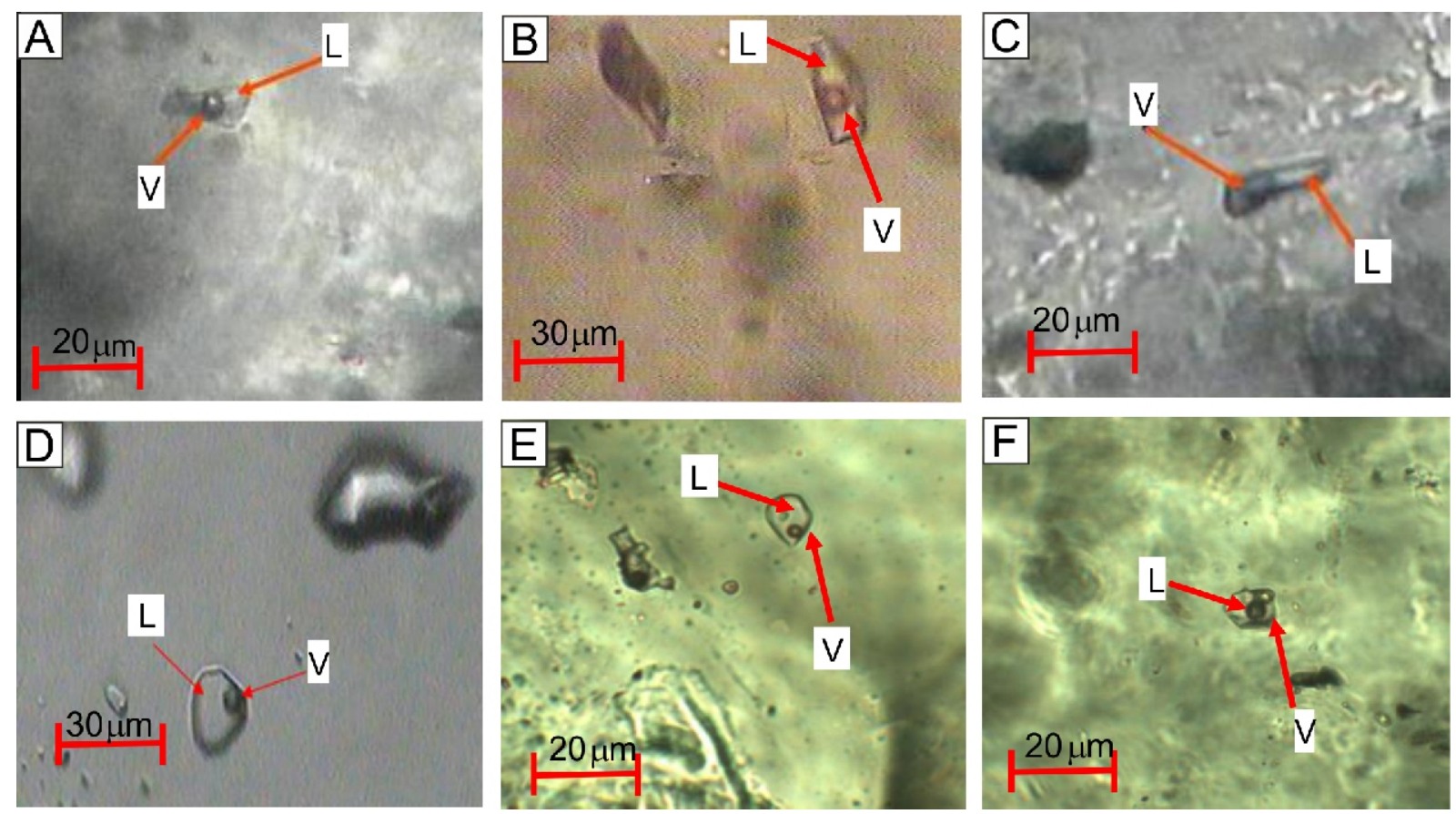

Fig. 8. Photomicrographs of primary fluid inclusions at: A -Sungun, B - Sonajil, C - Mazraeh, D - Nabijan, E Mazraeh-e-Shadi, F - Zaglic

$$
\mathrm{L} \text { - liquid, } \mathrm{V} \text { - vapour }
$$

These veins/veinlets contain sulfides (pyrite, chalcopyrite, molybdenite, bornite, galena, tetrahedrite, tenantite and enargite), hydroxides and oxides (magnetite and specularite) and carbonate (malachite and azurite) minerals. Activity of supergene solutions caused the formation of a predominantly goethite-enriched cap containing copper oxides and carbonates. Low pyrite abundance, outcropping of the potassic zone, rapid uplift, a basic composition of the host stock and low hypogene grade are the reasons for poor secondary chalcocite enrichment in a form of poorly developed blanket.

Various types of fluid inclusion including mono-phase vapour, two-phase liquid and vapour (Fig. 8B), and multiphase liquid-vapour-solid of primary origin are present within quartz-sulfide veinlets. $T_{H}(L-V)$ for halite-bearing inclusions homogenizing by the disappearance of halite and of vapour are $260-565^{\circ} \mathrm{C}$ and $320-520^{\circ} \mathrm{C}$, respectively and salinity is $35.3-69 \% \mathrm{NaCl}$. $\mathrm{T}_{\mathrm{H}}(\mathrm{L}-\mathrm{V})$ for two-phase inclusion homogenization temperatures are $180-565^{\circ} \mathrm{C}$, and salinity is $0.7-15.17 \%$ $\mathrm{NaCl}$. In a bivariate plot of $\mathrm{T}_{\mathrm{H}}$-salinity, two distinct populations of high and low salinity fluids are recognizable and most of the data points relating to the high-salinity plot above the halite saturation curve. The coexistence of vapour-rich two-phase and halite-bearing inclusions having similar $T_{H}$ ranges can indicate boiling in the Sonajil porphyry deposit.

\section{SKARN DEPOSITS}

The skarn deposits of the Ahar region can be classified petrologically into endoskarn, exoskarn and ore skarn. Each of these can be further subdivided on the basis of the predominant mineral assemblage. Skarn mineralogy can be complex (Meinert et al., 2005). The dominant skarn minerals are garnet, calcite, pyroxene, actinolite and epidote which are accompanied by quartz, feldspar, minor vesuvianite and hornblende.

Copper-iron skarn deposits occur prominently in the AMZ along the intrusive contacts of the Oligo-Miocene granodiorite-monzonite plutons with the Cretaceous limestones. The most important skarn deposits in this zone are at Mazraeh, Anjerd, Javanshaykh and Gavdel. In the Sungun district, copper-skarn deposits are found close to the porphyry copper at the contact between a hypabyssal monzodiorite intrusion and a Cretaceous limestone. The Sungun skarn was previously mined in the 1920s by the Soviet Union. Porphyry stock emplacement led to the formation of contact metamorphism and skarn-type mineralization along its border with carbonates at the north-east of the Sungun open pit (Calagari and Hosseinzadeh, 2006). The associated contact metasomatic alteration and skarn mineralization are best developed in places where the fracture density in the carbonate rocks is relatively high. Metasomatic effects are well pronounced at the contact of the porphyry stock with carbonate rocks, and diminish gradually outwards up to $55 \mathrm{~m}$ from the contact.

Einaudi (1982) distinguished between reaction skarns and ore skarns. The former, of limited extent, are formed along shale-limestone contacts during metamorphism. The latter, as the name implies, are the skarns that contain mineralisation, and are formed as a result of infiltration of fluids derived from igneous intrusions. In the Ahar region the processes that lead to the formation of skarn deposits include three stages as follows: (1) Emplacement of plutonic magma which leads to isochemical contact metamorphism (calcite, pyroxene, plagioclase); (2) prograde metasomatic skarn formation as the pluton cools and an ore fluid develops, (epidote, tremolite/actinolite, chlorite) and; (3) retrograde alteration of earlier formed mineral assemblages, leading to the formation of hydrosilicate minerals along with ore deposition (Mollai et al., 2014). In general, skarns are zoned from endoskarns in the causative pluton, to proximal garnet and distal pyroxene, a pattern which also indicates the overall oxidation state of the skarn system (Meinert et al., 2005).

Weak skarn mineralization occurs also at the contact of the Mivehrud subvolcanic body with Upper Cretaceous marly limestone in Zone $\mathrm{C}$. The mineral assemblage consists of chalcopy- 

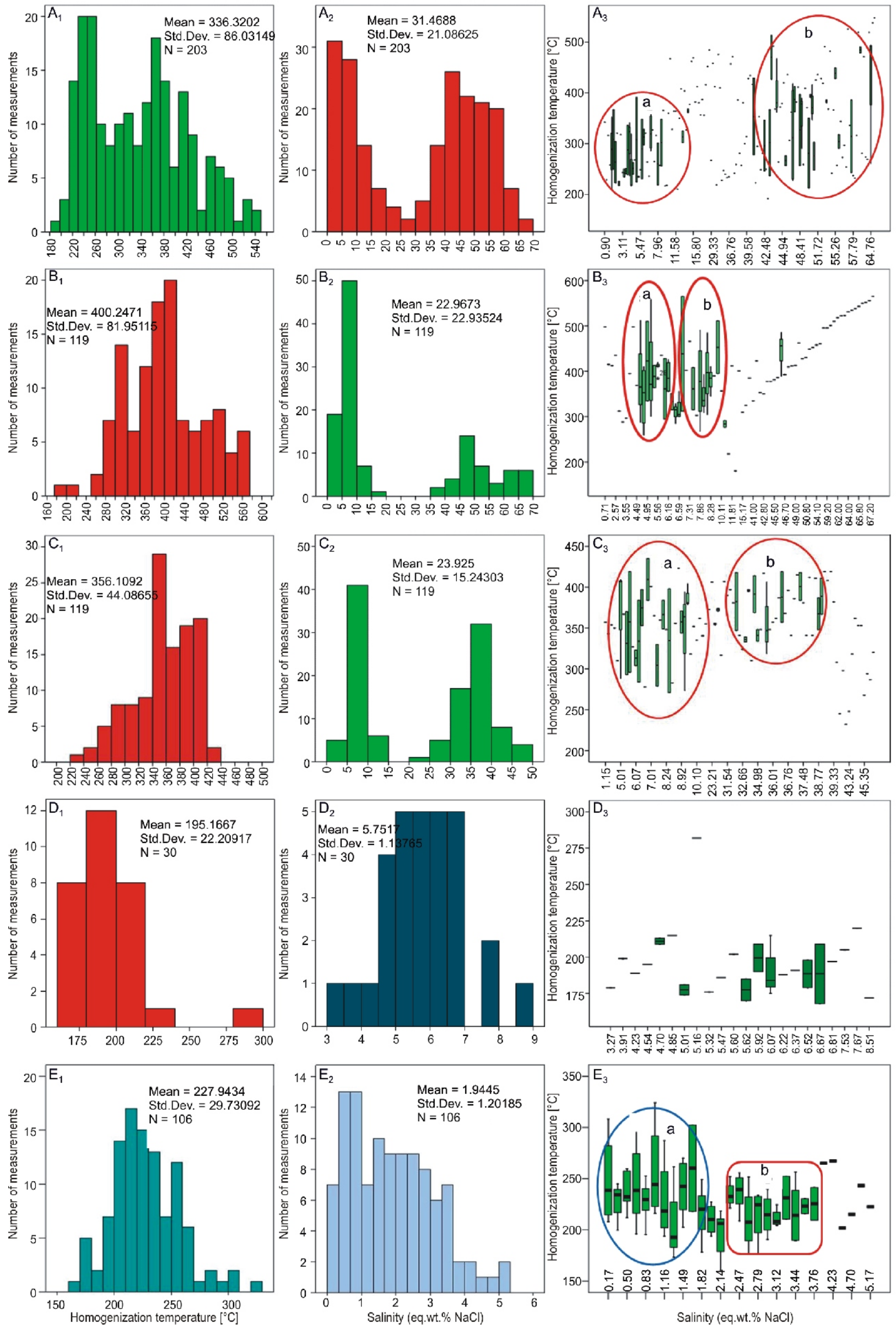

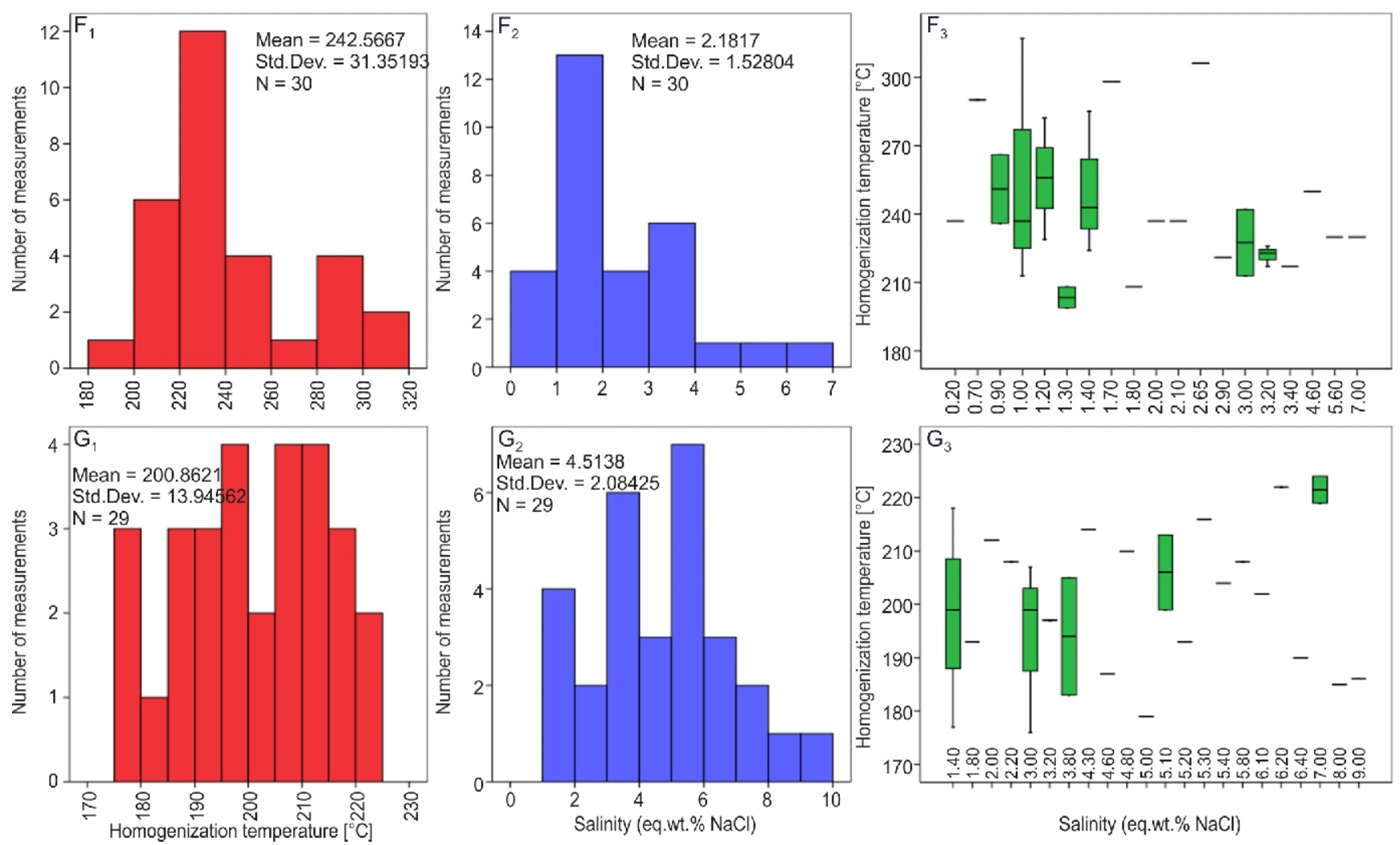

Fig. 9. Histogram of homogenization temperatures, salinity and plots of homogenization temperatures vs. salinity (wt.\% NaCl equivalent) for all fluid inclusions showing two populations

Each box shows the median, quartiles, and extreme values within a category: A - Sungun, B - Sonajil, C - Mazraeh, D - Nabijan, E Mazraeh-e-Shadi, F - Zaglic, G - Safikhanlo

rite-pyrite-magnetite with minor galena, sphalerite, and molybdenite, as well as andradite, grossular, epidote, and pyroxene (Mollai, 1993; Atalu, 2006).

Textural examination shows that at least three types of garnet are distinguishable. From oldest to youngest these are as follows: (1) fine-to medium-grained, anisotropic garnets which are mainly present in the outer parts of the skarn zone. (2) Medium- to coarse-grained, subhedral to euhedral, dark brown garnets. They occur as patchy aggregates with conspicuous growth zoning, and are isotropic in their central zones, and anisotropic at their margins. (3) Veinlets of medium- to coarse-grained, isotropic and anisotropic garnets cross-cut type 2 garnets and partially replace them (Calagari and Hosseinzadeh, 2006). Optical anisotropy in garnet is due to their departure from cubic symmetry, as a result of partial replacement of $\left(\mathrm{SiO}_{2}\right)$ by $(\mathrm{OH})$ to form hydrogarnet. Rose and Burt (1979) suggested that anisotropic garnet will form due to fluctuation in fluid composition resulting from variable admixture with meteoric water. Zoned garnets from skarn deposits of the Ahar region do not show systematic compositional variation from the core to the rim of the crystal.

Mazraeh. Based on Mollai (1993), among skarn deposits along the northern margin of the Ahar from west to east, the Mazraeh $\mathrm{Cu}-\mathrm{Fe}$ skarn deposit is the most typical. It is located $20 \mathrm{~km}$ north of Ahar town (Fig. 7). The origin and development of the skarn can be related to a granitic intrusion of Miocene age, which has intruded a sequence of calcareous rocks. On the basis of petrological observations, the skarn can be subdivided into exoskarn, endoskarn and ore skarn (Mollai, 1993; Mollai et al., 2009). The main mineral constituents of the skarns are garnet, magnetite, calcite, chalcopyrite, epidote, hematite and pyroxene, accompanied by quartz, pyrite, bornite, coevalite, chalcocite, plagioclase and chlorite. The bulk chemistry and spatial variation indicate that the endoskarn was the result of interaction between the Mazreah granodiorite with crystalline limestone and metasomatic alteration by hydrothermal fluids enriched in $\mathrm{Mg}, \mathrm{Fe}, \mathrm{Cu}, \mathrm{P}, \mathrm{Ag}, \mathrm{Zn}, \mathrm{Pb}, \mathrm{Cd}, \mathrm{Mo}, \mathrm{Mn}$. These elements point towards a magmatic source, and have been contributed to the system from the magma as well as the host rock. The crystalline limestone was the source for $\mathrm{Ca}$ and $\mathrm{Mg}$ in the case of the endoskarn. The transformation of granodiorite into endoskarn was accomplished by addition of 1.4 to $15 \% \mathrm{CaO}$ along with $7.17 \%$ of total iron into the granodiorite, accompanied by $\sim 15.5 \%$ depletion in $\mathrm{SiO}_{2}$. The ore-stage is dominated by liquid-rich fluid inclusions (Fig. $8 \mathrm{C}$ ); vapour-rich inclusions are rare. The homogenization temperature varies between 435 and $232^{\circ} \mathrm{C}$ and salinity ranges from 1.15 to 49 wt. \% $\mathrm{NaCl}$ equivalents (Mollai,1993).

Nabijan. The Nabijan skarn deposit is located $40 \mathrm{~km}$ west of Kaleibar city, East Azerbaijan province in the Alborz-Azerbaijan structural zone (Fig. 2). Geological rock units outcropping in the area consist of volcano-sedimentary rocks (trachyandesite, andesite, shale and limestone) of Cretaceous age, intruded by Oligo-Miocene monzogranite, monzogranodiorite and diorite. These intrusions and related hydrothermal activities caused the Au mineralization of the Cretaceous host rocks, as well as of the monzogranites. The mineralization in the monzogranite occurred as a silicic stockwork and sheeted veins with pyrite and minor chalcopyrite, sphalerite and galena. The other type of mineralization is skarn, which is present as sparse irregular veinlets with 
small amounts of $\mathrm{Au}$ in the carbonates. Preliminary estimation of ore reserve amounts to $320 \mathrm{kt}$ with average Au grade $\sim 1.37 \mathrm{~g} / \mathrm{ton}$. Surface and drilling data enabled determination of two important anomalies. One is in the contact zone of intrusive rocks with the Cretaceous volcanics and carbonates, representing the skarn zone. In this anomaly, the correlation coefficient index between $\mathrm{Au}$ and $\mathrm{Cu}, \mathrm{Pb}, \mathrm{Zn}, \mathrm{Ag}$, and $\mathrm{As}$ is low, whereas in the second one which coincides with the stockwork mineralization within the monzogranite, it is high. The homogenization temperature varies between $168-224^{\circ} \mathrm{C}$ and salinity varies between $3.27-8.51 \mathrm{wt} . \%$ $\mathrm{NaCl}$ equivalent (Fig. 8D). The occurrence of hydrothermal breccias, bladed calcite, adularia, and rare coexisting vapour- and liquid-dominant inclusions suggest that boiling occurred during evolution of the ore fluids. The large variations in Th and the salinity values can be explained by boiling and/or mixing.

\section{EPITHERMAL MINERALIZATION}

Widespread, WNW-trending alteration zones that are parallel to the regional faults occur mainly within the Eocene volcanic rocks (e.g., Safikhanlo and Mazraeh-e-Shadi) of Zone B. The mineralization is restricted to silica, silica-carbonate, and silica-barite veins, although stockwork and sheeted veinlets occur locally. Pyrite is the main sulphide mineral and is associated with minor chalcopyrite, sphalerite, and galena. Gold is found as fine particles in silica and in sulphides. Some sericitic alteration occurs at deeper structural levels, where it is associated with quartz veins and veinlets that consist of transparent and milky quartz with crustiform and comb-like textures, typical of epithermal mineralization environments. Fluid inclusion studies show a wide range of homogenization temperatures $\left(120-350^{\circ} \mathrm{C}\right)$ and salinity (1-15 wt. $\% \mathrm{NaCl}$ equivalent). A positive correlation exists between the higher salinities and the high base metal contents in the veins (Ebrahimi et al., 2009).

Zaglic and Safikhanlo. The Zaglic and Safikhanlo epithermal gold prospects are located to the west of the Cenozoic AAMB in NW Iran. These prospects are characterized by extensive outcrops of Cretaceous flysch type strata and Cenozoic volcanic and plutonic rocks. They are only $4 \mathrm{~km}$ apart, and lie in an area covered by Eocene-Miocene volcanic, pyroclastic and intrusive rocks. The oldest rocks include dark grey to green, porphyritic andesite, basaltic andesite, trachy-andesite to latite-andesite of Upper Eocene age. The rocks consist mainly of plagioclase (andesine-oligoclase), hornblende, clinopyroxene and subordinate biotite and quartz. The dominantly andesitic lavas are overlain by light to dark green, fine-grained tuff of intermediate composition, with scattered crystals of plagioclase, hornblende, pyroxene and biotite, as well as andesitic tuff breccias and andesitic breccias. The volcanic-pyroclastic succession in Safikhanlo was intruded by a hypabyssal intrusion composed dominantly of syenite associated with subordinate granite and monzosyenite. The intrusive rocks consist mainly of plagioclase, alkali feldspars, quartz, hornblende, and biotite. Apatite and Fe-Ti oxides are common accessory minerals. An Oligocene age is proposed for the intrusion by analogy with similar intrusions in the Ahar quadrangle. Numerous acidic to intermediate dykes intruded the Upper Eocene volcanic and pyroclastic rocks and the Oligocene intrusive rocks. The dykes vary in length and width between $50-500$ and $1-20 \mathrm{~m}$, respectively.

Mineralization is mainly restricted to quartz and quartz-carbonate veins and veinlets. Pyrite is the main sulphide, associ- ated with subordinate chalcopyrite and bornite. Gold occurs as microscopic and submicroscopic grains in quartz and pyrite.

Host volcanic rocks from both Safikhanlo and Zaglic areas are medium- to high-K, calc-alkaline and alkaline rocks and display fractionated REE patterns, with LREE significantly enriched relative to the HREE. On primitive mantle-normalized plots, they display depletions in $\mathrm{Nb}, \mathrm{Ti}$ and $\mathrm{P}$, and enrichments in $\mathrm{Pb}$, which are common characteristics of arc-related magmas worldwide. Hydrothermal alteration minerals developed in the wall rocks include quartz, calcite, pyrite, kaolinite, montmorillonite, illite, chlorite, and epidote. Minor alunite occurs at Safikhanlo. Gold is locally enriched in the altered rocks immediately adjacent to the veins. The ore-stage quartz from both prospects is dominated by liquid-rich fluid inclusions (Fig. 8E); vapour-rich inclusions are rare. The homogenization temperature varies between $176-224$ and $199-317^{\circ} \mathrm{C}$ and salinity varies between 1.4-9.6 and from $<1$ to $6.7 \mathrm{wt} . \% \mathrm{NaCl}$ equivalent, for Safikhanlo and Zaglic, respectively. The occurrence of hydrothermal breccias, bladed calcite, adularia, and vapour- and liquid-dominant inclusions suggests that boiling resulted from the evolution of ore fluids. The large variations in Th and the salinity values can be explained by boiling and/or mixing. A lack of sulphate minerals in the veins suggests that sulphides and gold precipitated from a reduced, $\mathrm{H}_{2} \mathrm{~S}$-dominant fluid. The $\delta^{34} \mathrm{~S}$ values for the ore fluid vary between -4.6 and $-9.3 \%$. Sulphur could have been derived directly from magmatic sources, or leached from the volcanic and plutonic country rocks (Alirezaei et al., 2011). Ore formation in the Zaglic and Safikhanlo areas occurred in response to mixing, boiling, and interactions with wall rocks. Considering the intermediate-argillic alteration, low contents of base metal sulphides, and the overall low salinities, the Zaglic and Safikhanlo occurrences can be classified as low-sulphidation epithermal systems.

Mazraeh-e-Shadi. The Mazraeh-e-Shadi epithermal deposit is located $\sim 130 \mathrm{~km}$ to the north-east of Tabriz in the magmatic rocks of the central Iranian geostructural zone (Fig. 2). More than $10 \mathrm{Cu} \pm \mathrm{Mo} \pm \mathrm{Au}$ porphyry deposits and epithermal gold systems have been identified in the Arasbaran metallogenic zone, e.g. Sungun (Calagari, 1997), Mazraeh, Sungun and Anjerd (Mollai, 1993; Calagari and Hosseinzadeh, 2006; Karimzadeh Somarin and Moayyed, 2002), Masjeddaghi (Akbarpur, 2007), Zaglic (Heidarzadeh, 2006), Safikhanlo (Gadimzadeh, 2002), Sharafabad (Purnik, 2006; Ebrahimi et al., 2009).

In the Mazraeh-e-Shadi area three types of lithologies are represented (Radmard et al., 2017), as follows: Eocene pyroclastic rocks, Oligocene-Pliocene volcanic rocks, and Quaternary volcanogenic conglomerate (agglomerate) and alluvial units.

The Eocene pyroclastic, volcanic and agglomeratic rocks (usually of an andesitic composition) are overlain by dacitic tuff, dacite, hornblende andesite, trachyandesite and andesite volcanic rocks of Oligocene and Pliocene age. Numerous dacite to andesitic dykes intruded into the volcanic and pyroclastic rocks are of Upper Eocene age. The youngest rock units in the area are Quaternary alluvial plain and river deposits. The Quaternary volcanogenic conglomerate (agglomerate) crops out in the vicinity of the Mazraeh-e-Shadi deposit in the southwestern part of the study area. Subvolcanic rocks such as quartz monzodiorite-diorite porphyry intruded the Eocene volcanic and volcano-sedimentary units and caused mineralization and alteration. Gold mineralization in the Mazraeh-e-Shadi is related to Eocene volcanic and intrusive rocks. Outcrops of subvolcanic 


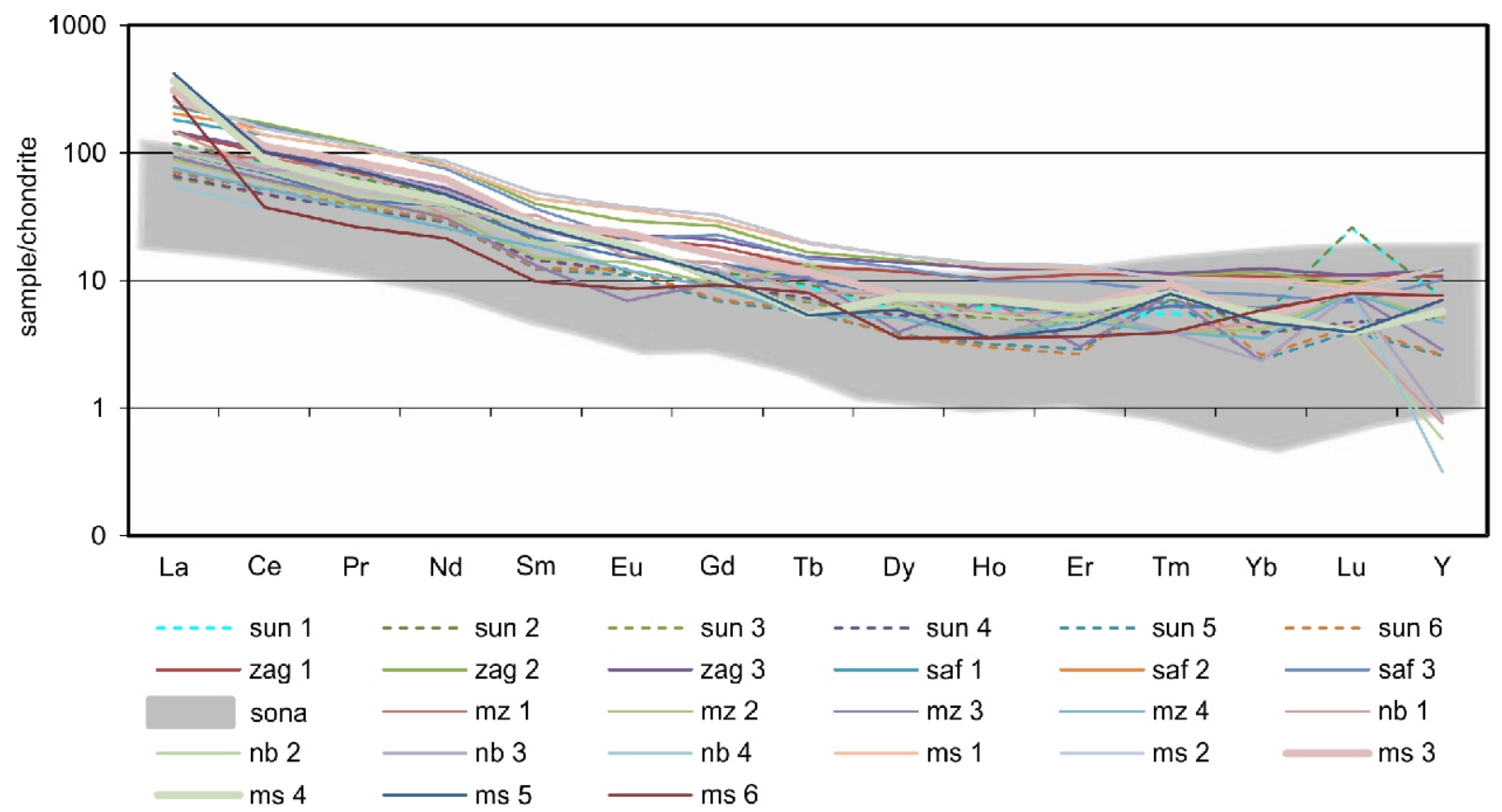

Fig. 10. Chondrite-normalised REE patterns (according to Taylor and McLennan, 1985) of fresh samples from the Sungun, Zaglic, Safikhanlo, Nabijan, Mazraeh, Mazraeh-e-Shadi and Sonajil deposits

sun - Sungun, zag - Zaglic, saf - Safikhanlo, sona - Sonajil, mz - Mazraeh, nb - Nabijan, ms - Mazraeh-e-Shadi

rocks extend over a distance of $\sim 1650 \mathrm{~m}$ and their width ranges from 300 to $450 \mathrm{~m}$ in the area.

Three main types of fluid inclusions were identified in the samples collected from silicified and mineralized zones; Type 1 - liquid-rich fluid inclusions (LV) consists of liquid + vapour with the liquid phase volumetrically dominant, and lack daughter crystals (Fig. 8F). The diameters of these fluid inclusions ranges from 4 to $92 \mu \mathrm{m}$. These fluid inclusions are common in all the mineralized quartz veins. They occur in almost all samples and made up the largest numbers of the inclusions studied. The first ice-melting temperatures $\left(T_{f m}\right)$ of these inclusions range from -19 to $-29^{\circ} \mathrm{C}$ and the last ice-melting temperature ( Tm ice) is between -3.2 and $2.2^{\circ} \mathrm{C}$. These inclusions yield homogenization temperatures from 160 to $308^{\circ} \mathrm{C}$ and salinities are 0.17-5.2 wt.\% $\mathrm{NaCl}$ equivalent. Type 2 - two-phase vapour-rich (VL) fluid inclusions are common in exposure quartz vein samples. The diameters of these fluid inclusions ranges from 6 to $17 \mu \mathrm{m}$. These inclusions homogenized to a gas phase. The homogenization temperatures, ranging from between 173 and $324^{\circ} \mathrm{C}$, are the highest homogenization temperatures obtained from quartz in the study area and salinities are $0.16-1.8$ wt. $\% \mathrm{NaCl}$ equivalent. The gas bubbles in the $(\mathrm{VL})$ inclusions occasionally occupy $>80 \%$ of the inclusion volume. Type 3 - vapour monophase (V) inclusions have sizes from 10 to $31 \mu \mathrm{m}$ (Radmard et al., 2017). Quartz veins containing liquid-rich and vapour-rich inclusions indicate boiling during hydrothermal evolution, resulting in relatively higher gold grades (up to $813 \mathrm{ppb} \mathrm{Au}$ ).

\section{GEOCHEMISTRY OF RARE EARTH ELEMENTS}

The study of REE behaviour in rocks and minerals is of note for the following reasons. First, REEs induced special behaviours during various geochemical processes, which are used as detectors in recognition of ores and rock origin as well as of geological and tectonic settings. Secondly, environmental issues are highly significant to radioactive wastewater management and REEs are known as fissionable plutonium and uranium products in nuclear power plants (Brooking, 1984; Rard, 1988). Thirdly, economically speaking, they have several applications of extraordinary value. REEs are conveniently divided into three subgroups: HREE, MREE and LREE (Rollinson, 1993). The fractionation degree between REEs can be determined by the LREE/HREE ratio. It has been pointed out that replacement of REEs by calcium is one of their significant features (Knarchenko and Pokrovsky, 1995; Pollard, 1995).

Geochemical considerations indicate that the concentration values of rare earth elements in the deposits range from 55 to 234 ppm (Appendix 1*).

Patterns of the chondrite-normalised REE for the Sungun, Mazraeh, Mazraeh-e-Shadi, Sonajil, Nabijan, Safikhanlo and Zaglic deposits show that, although the distribution pattern of REEs is more or less flat and smooth, LREEs show higher concentrations than HREEs (Fig. 10). This indicates that considerable differences of gain and loss occurred between LREEs and HREEs during the formation of the rocks. The distribution patterns of LREEs, MREEs and HREEs are shown in Figures 11 and 12. The highest values of the LREEs, MREEs and HREE ratios have been observed in the epithermal deposits (e.g., Mazraeh-e-Shadi, Safikhanlo and Zaglic).

To evaluate the fractionation degree between REEs, various ratios of REEs, such as $(\mathrm{La} / \mathrm{Yb}) \mathrm{n},(\mathrm{La} / \mathrm{Sm}) \mathrm{n}$ and $(\mathrm{Gd} / \mathrm{Yb}) \mathrm{n}$ were used. $(\mathrm{La} / \mathrm{Yb}) \mathrm{n}$ determines the degree of fractionation of LREEs from HREEs during geochemical processes (Aubert et al., 2001; Yusoff et al., 2013), while the two other ratios establish the degree of fractionation between LREEs and MREEs and between MREEs and HREEs, respectively (Yusoff et al., 2013).

The values of these ratios range for $(\mathrm{La} / \mathrm{Yb}) \mathrm{n}$ from 8.88 to 88.77, for $(\mathrm{La} / \mathrm{Sm}) \mathrm{n}$ from 3.36 to 28.41 and for $(\mathrm{Gd} / \mathrm{Yb}) \mathrm{n}$ from 1.57 to 5.17 (Appendix 2). The greatest fractionation occurred 


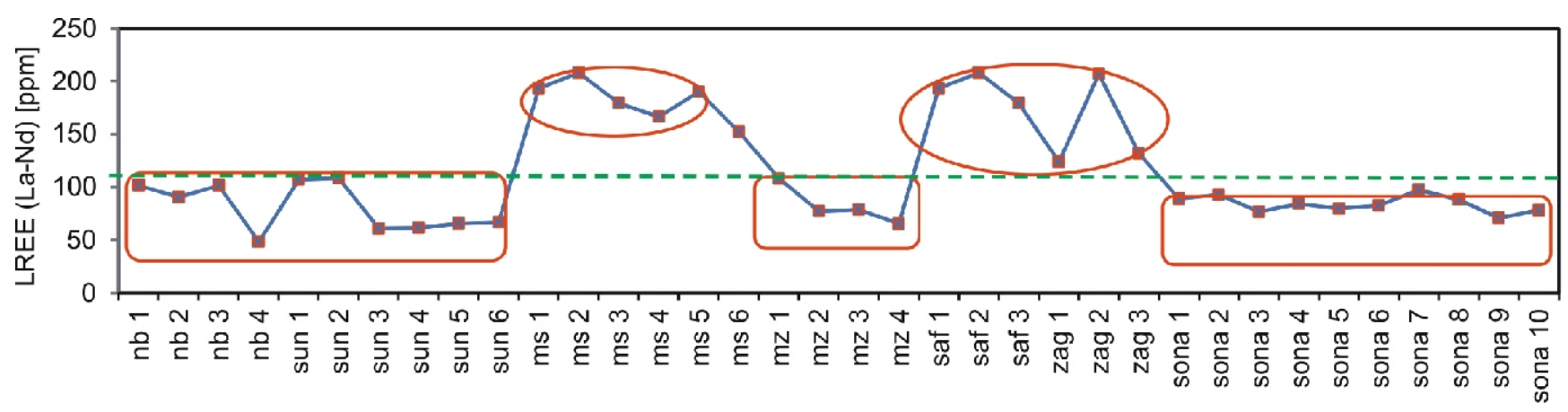

Fig. 11. Concentration variations of LREEs (La-Nd)

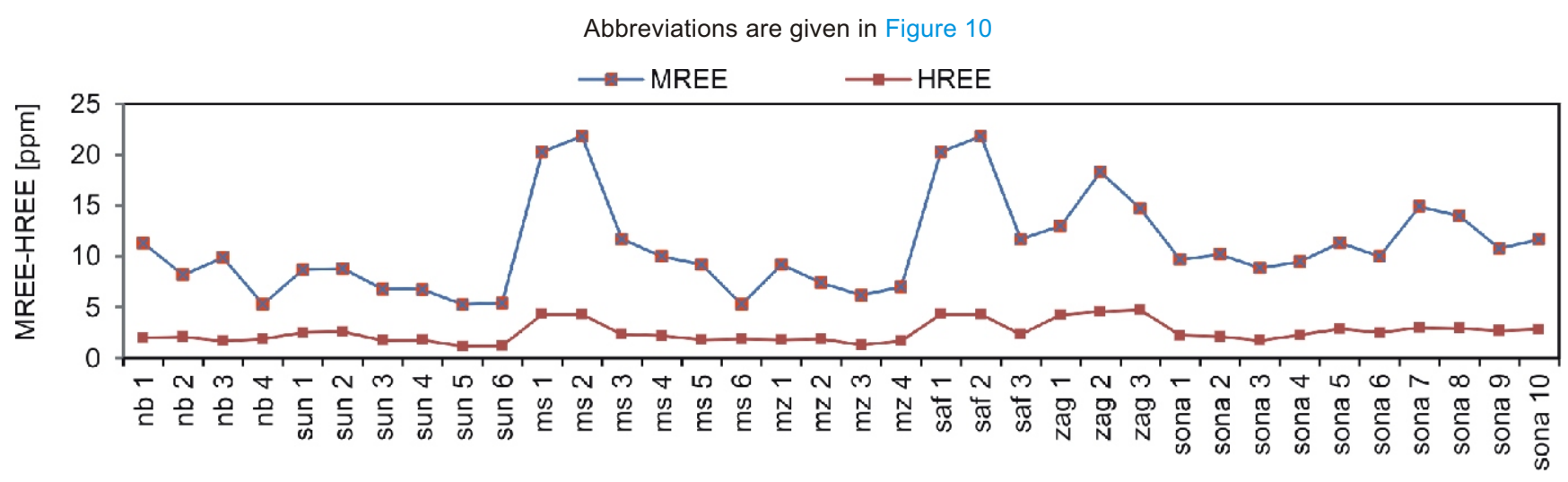

Fig. 12. Concentration variations of MREE and HREEs

Abbreviations are given in Figure 10

between LREEs and HREEs (up to 89 times) with a relatively minor fractionation between MREEs and HREE. These ratios reflect fractionations as follows: LREE/HREE > LREE/MREE> MREE/HREE. The highest values of the three ratios have been observed in the Mazraeh-e-Shadi and Nabijan deposits (Appendix 1): $(\mathrm{La} / \mathrm{Yb}) \mathrm{n}=89,(\mathrm{La} / \mathrm{Sm}) \mathrm{n}=28.41$ and $(\mathrm{Gd} / \mathrm{Yb}) \mathrm{n}=$ $5.17)$ that represent large fractionation of REE in the Mazraeh-e-Shadi deposit not only because of high LREE but also on account of low MREE and HREE. Since the distribution pattern of REEs is governed by mainly geochemical conditions, the $L a / Y$ ratios render useful data for determination of $\mathrm{pH}$ in the environment of ore formation. Values of $L a / Y>1$ show alkaline conditions, while values of $\mathrm{La} / \mathrm{Y}<1$ indicate acidic conditions
(Crinci and Jurkowic, 1990). This ratio in this region ranges from 1.32 to 29.17 (Appendix 2 and Fig. 13).

Calculations of Eu and $\mathrm{Ce}$ anomalies are defined by the following equations (Taylor and McLennan, 1985): $\mathrm{Ce} / \mathrm{Ce}^{*}=$ (2Ce/Ce chondrite)/ (La/La chondrite + $\mathrm{Pr} / \mathrm{Pr}$ chondrite) and $\mathrm{Eu} / \mathrm{Eu}^{*}=(2 \mathrm{Eu} / \mathrm{Eu}$ chondrite $) /(\mathrm{Sm} / \mathrm{Sm}$ chondrite $+\mathrm{Gd} / \mathrm{Gd}$ chondrite). The $\mathrm{Eu}$ and $\mathrm{Ce}$ anomaly values across the lithological units range from $0.60-1.29$ and $0.61-0.98$, respectively (Appendix 1 and Fig. 14). Values $>1$ and $<1$ are called positive and negative anomalies, respectively. Plotting the $\mathrm{Ce} / \mathrm{Ce}^{*}$ values of all samples on a Ce/Ce* vs. $\mathrm{R}$ REs binary diagram represents one population including $<1$. This situation is also repeated for Eu/Eu* and (Pr/Yb)n (Fig. 15).

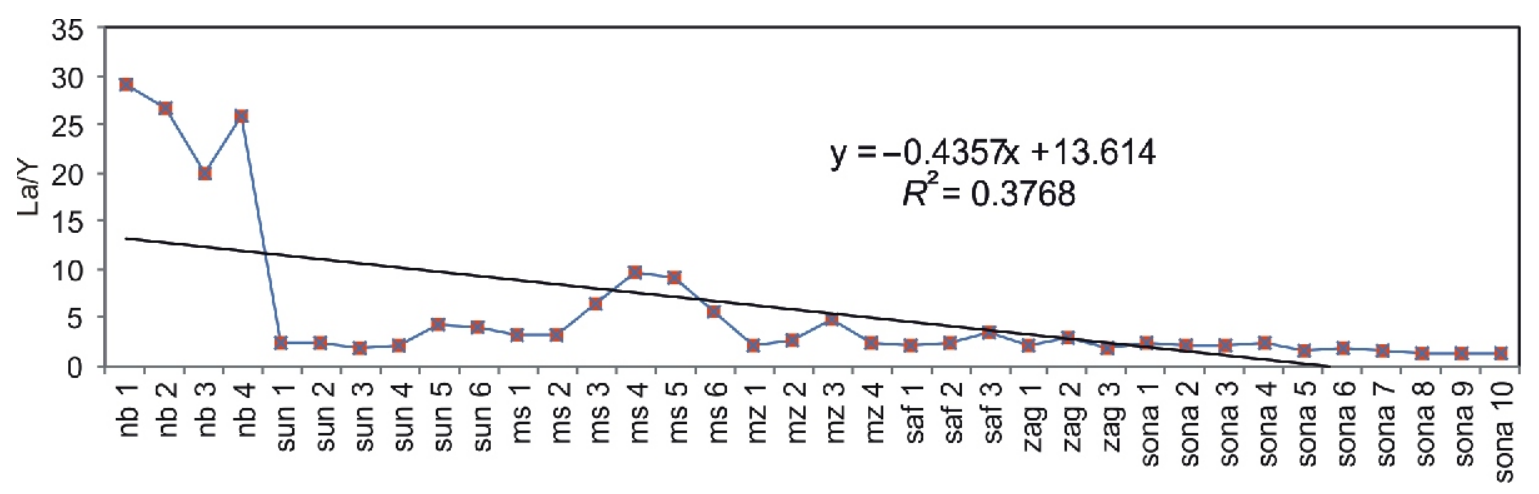

Fig. 13. Variations of La/Y values

Abbreviations are given in Figure 10 


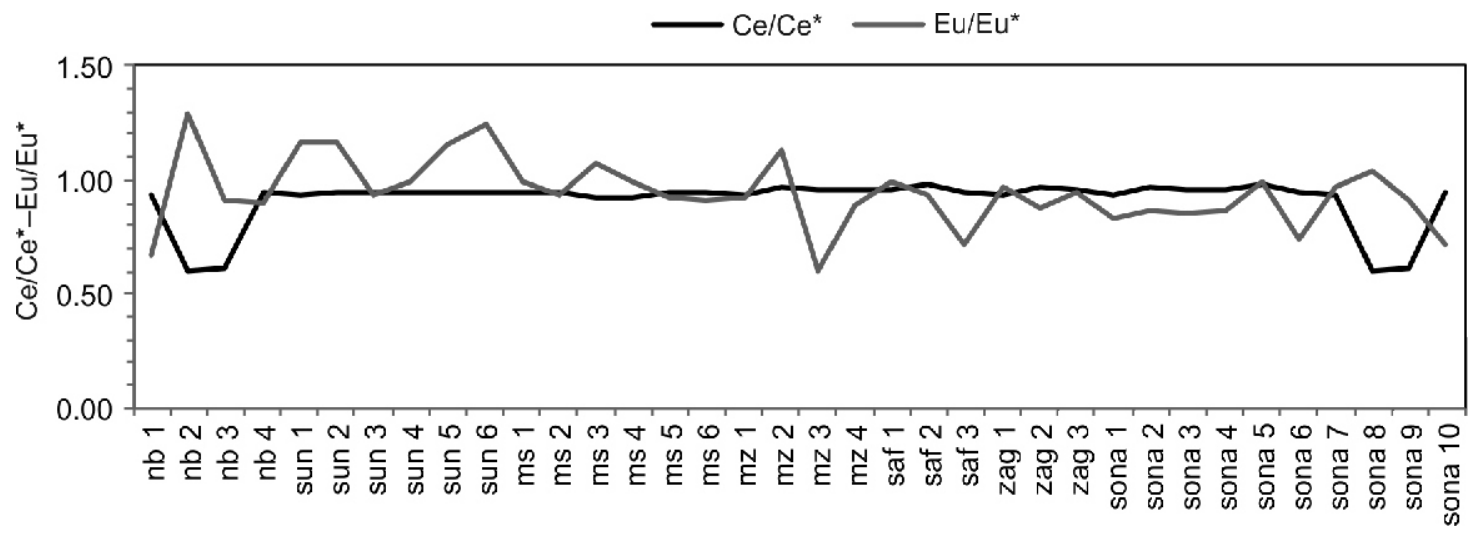

Fig. 14. Variations of $\mathrm{Ce} / \mathrm{Ce}^{*}$ and $\mathrm{Eu} / \mathrm{Eu}^{*}$ values

Abbreviations are given in Figure 10
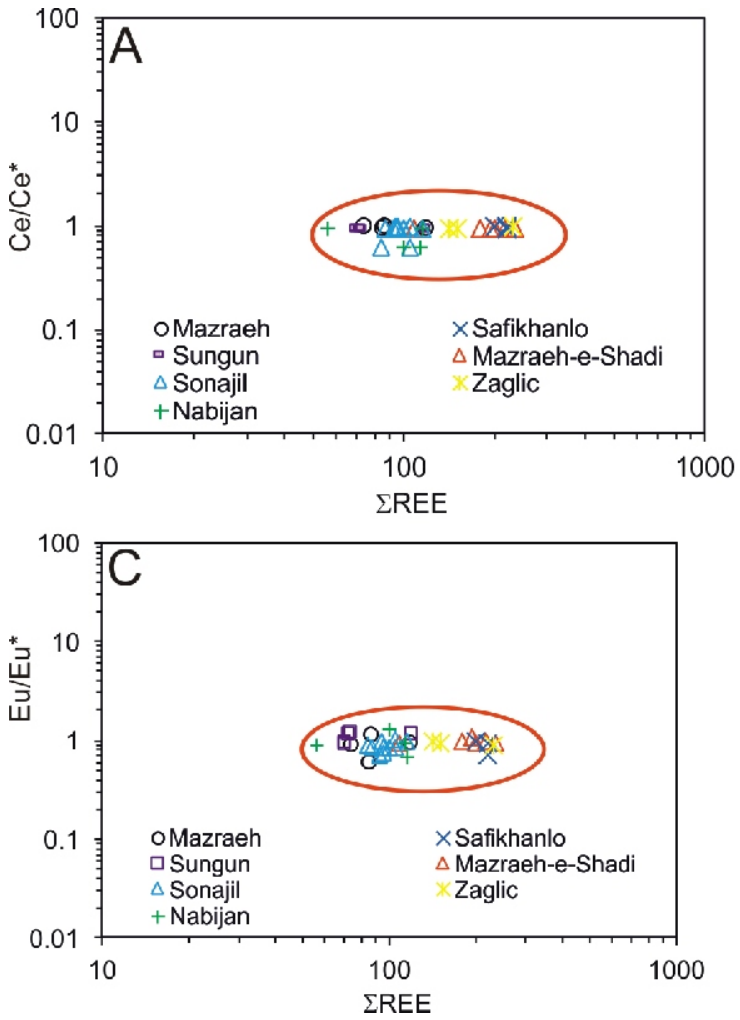

DISCUSSON

REEs. Rare earth element variations across the all deposits are similar indicating a similar source for the REE. All the deposits along the profile from Nabijan to the Sonajil show chiefly alkaline character. As the shear zones formed under relatively similar PT conditions, it is likely that the stability of the REE-bearing minerals was controlled by the characteristics of the fluids, i.e., $\mathrm{pH}$, oxygen fugacity ( $\mathrm{fO} 2$ ) and concentrations of potential REE ligands $\left(\mathrm{SO}_{4}^{-2}, \mathrm{CO}_{3}^{-2}, \mathrm{OH}^{-}, \mathrm{F}^{-}, \mathrm{PO}_{4}^{-2}\right)$. These $\mathrm{REE}$ ligands may precipitate into $R E E$ minerals or $R E E$-bearing minerals in response to changes in fluid composition, because of fractional crystallization, fluid-rock reaction, or fluid-mixing processes (Rolland et al., 2003). Precipitation and dissolution of various REE minerals at different stages of shear zone formation illustrate that changes in fluid chemistry occurred in individual shear zones (Rolland et al., 2003). The Nabijan deposit has the highest $L a / Y$ values (29.17), indicating basic conditions of hydrothermal alteration during mineralization (Fig. 13). The basic conditions of hydrothermal alteration decrease from epither-

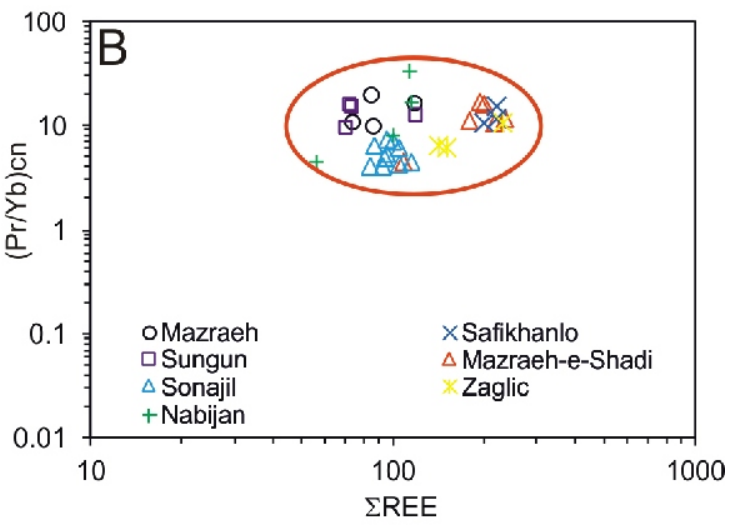

Fig. 15A - relationship between $\mathrm{Ce} / \mathrm{Ce}{ }^{*}$ vs. $\Sigma \mathrm{REE}$; B - (Pr/Yb)cn vs. $\Sigma$ REE; C - Eu/Eu* vs. $\Sigma$ REE in the Sungun, Zaglic, Safikhanlo, Nabijan, Mazraeh, Mazraeh-e-Shadi and Sonajil deposits

mal deposits to the porphyry and skarn deposits, from the north to the south and west to east due to the relationships between these deposits (Fig. 13). This relationship indicates that porphyry and skarn deposits have an early age and epithermal deposits are later in origin.

All the deposits, based on the REE values and Ce anomalies, can be grouped into one category with an alkaline $\mathrm{pH}$, negative $\mathrm{Ce}$ anomalies and high REE values. This is in fact an enrichment zone. The positive anomalies of $\mathrm{Ce}$ indicate that $\mathrm{Ce}$ was fixed as $\mathrm{Ce}^{4+}$ under acidic and oxidising conditions. The only logical and acceptable factor for the negative anomalies for $\mathrm{Ce}$ in this region is the coupled complexation of $\mathrm{Ce}^{4+}$ with carbonate ligands and its leaching during the mineralization processes (Karadag et al., 2009).

Since the Eu carriers are plagioclases, Eu concentrations might be related to the degree of plagioclase alteration. The Eu positive anomaly strongly indicates early stages of rock alteration in acidic environments (Kikawada, 2001). The positive anomalies of Eu and ( $\mathrm{La} / \mathrm{Lu}) \mathrm{n}$ imply acidic fluids at high temperature (Wood, 1990). Considering the three parameters Ce/Ce*, 

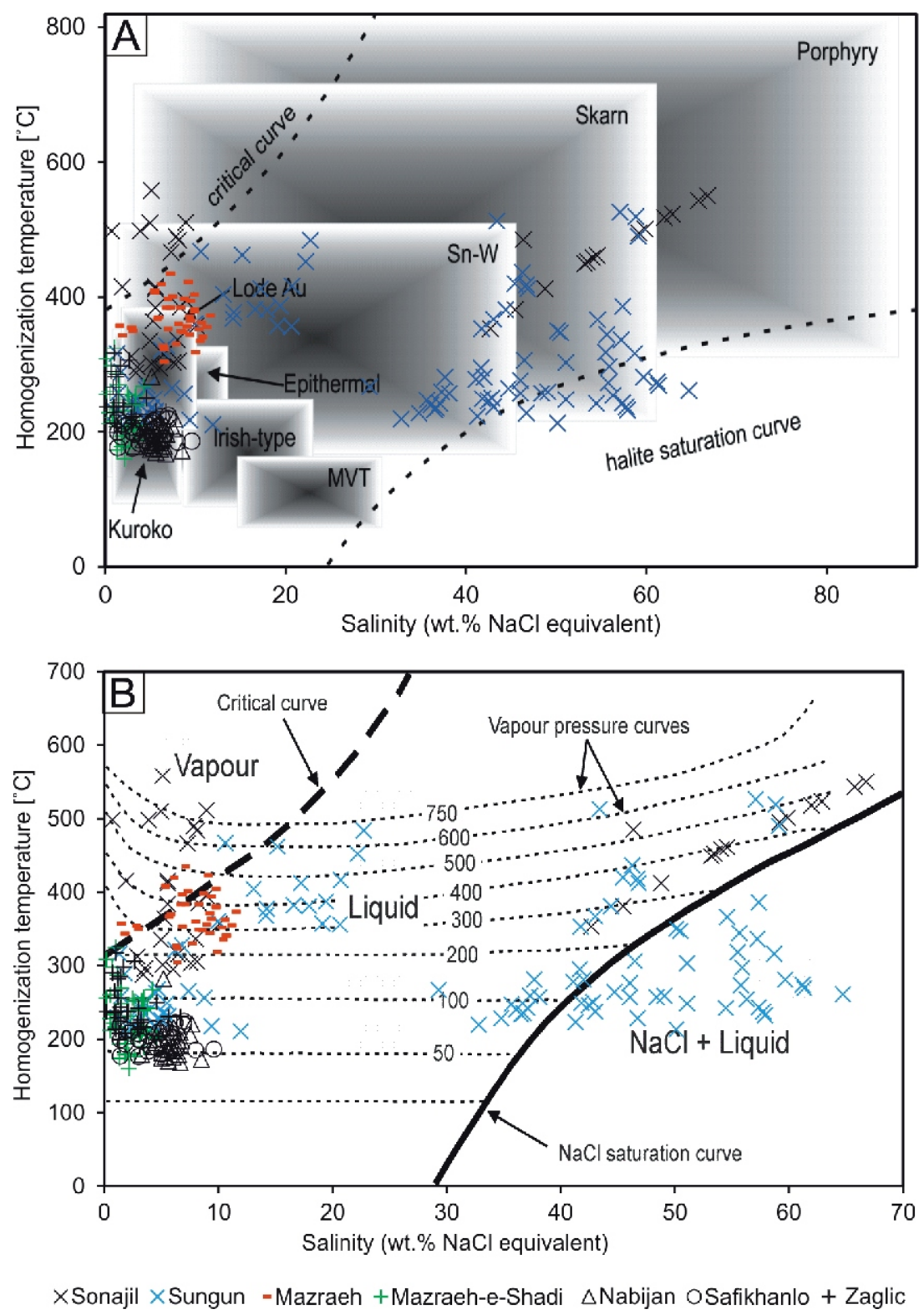

Fig. 16. Plots of salinity versus homogenization temperatures of primary fluid inclusions

$\mathrm{Eu} / \mathrm{Eu}^{*}$ and $(\mathrm{Pr} / \mathrm{Yb}) \mathrm{n}$ in all the deposits indicates alkaline and redox conditions of hydrothermal fluids enriched in REE with negative anomalies of Eu and $\mathrm{Ce}$ (Fig. 15). Geochemically, these deposits show similar major and trace element characteristics and overlapping inter-element ratios, indicating common melt sources; their enrichment in light lithophile element and high incompatible element abundances suggests derivation of their magmas from a subduction-metasomatized, subcontinental lithospheric mantle source.

Fluid inclusions and the mineralization age. Plots of salinity versus homogenization temperatures for fluid inclusions (Fig. 9) indicate that two types of hydrothermal fluids participated in the formation of all deposits: (a) high temperature and (b) low temperature fluids. At Zaglic, Safikhanlo and Nabijan the two types of hydrothermal fluids are unclear due to insufficient microthermometric data.

Projection of microthermometry data of fluid inclusions on the Th versus salinity diagram (Fig. 16A) indicates characteristics of a typical epithermal, skarn and porphyry deposit. Fig- ure $15 \mathrm{~B}$ shows that mineralization has taken place in a temperature range of 150 to $585^{\circ} \mathrm{C}$. The depth of mineralization (Fig. 17) decreases from porphyry and skarn deposits (Sungun, Sonajil and Mazraeh) to the epithermal deposits (Mazraeh-e-Shadi, Zaglic and Safikhanlo).

In this region most deposits show concentric zonation, with the centres preserving porphyry and skarn deposits (i.e. Sungun, Sonajil and Mazraeh), and outer deposit types becoming progressively epithermal (i.e. Mazraeh-e-Shadi, Zaglic and Safikhanlo). As follows from Table 1, mineralization is characterized by a pronounced regional zonation in the age and distribution of metals. The mineralization age decreases from the north to the south and east to west, and from the porphyry and skarn deposits to the epithermal deposits (Fig. 18). Although metal zonation is complex, the metal content changes from a $\mathrm{Cu}-\mathrm{Mo}$ to $\mathrm{Cu}-\mathrm{Au}$ association with time, reflecting an ore fluid that evolved in terms of both cooling and chemical changes due to fluid-fluid and fluid-rock interactions. 


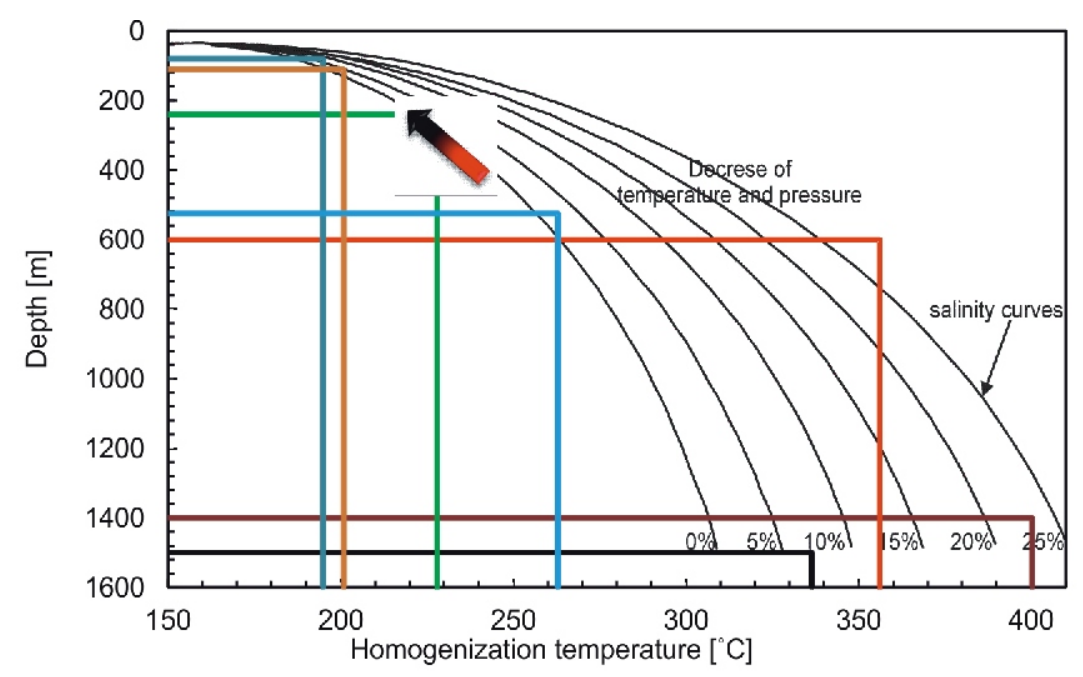

-Sonajil —Sungun —Mazraeh —Mazraeh-e-Shadi —Nabijan —Safikhanlo —Zaglic

Fig. 17. Plots of homogenization temperatures vs. depth for all fluid inclusions in all deposits (Hass, 1971)

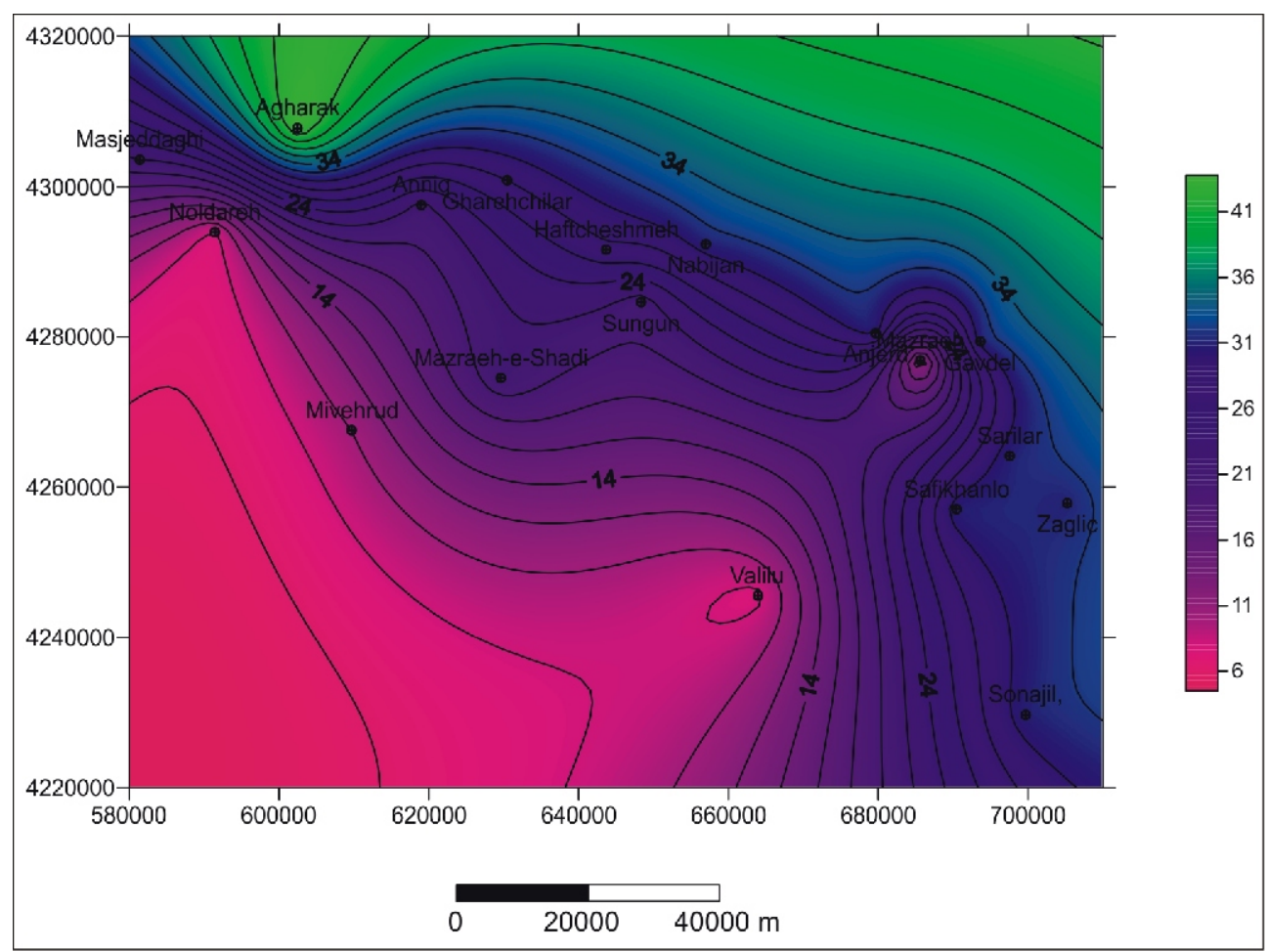

Fig. 18. Variation of the magmatism/mineralization age in the AMZ and its extension northwards to the Lesser Caucasus

The mineralization age decreases from the north-east to the south-west 


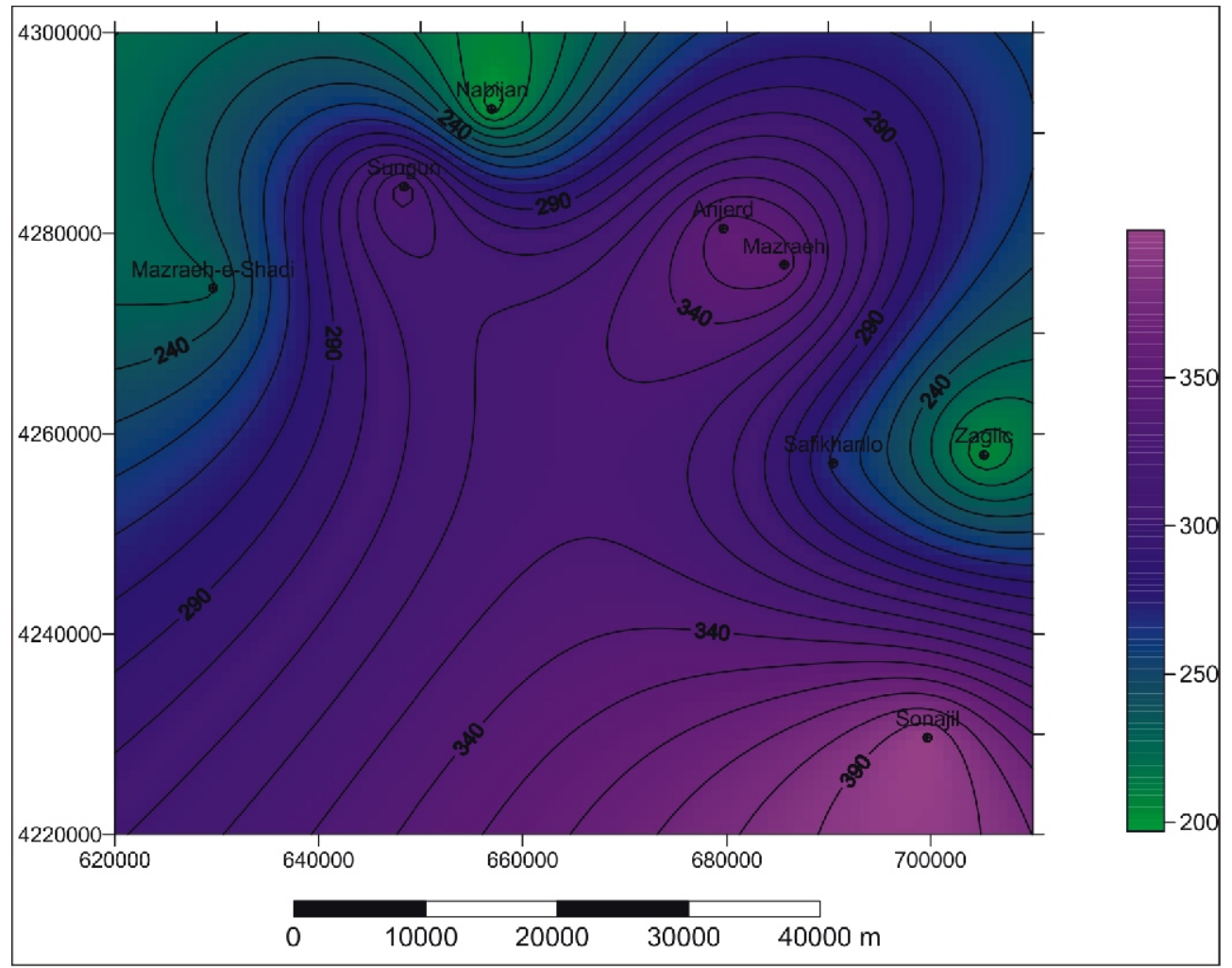

Fig. 19. The homogenization temperature $\left({ }^{\circ} \mathrm{C}\right)$ variation

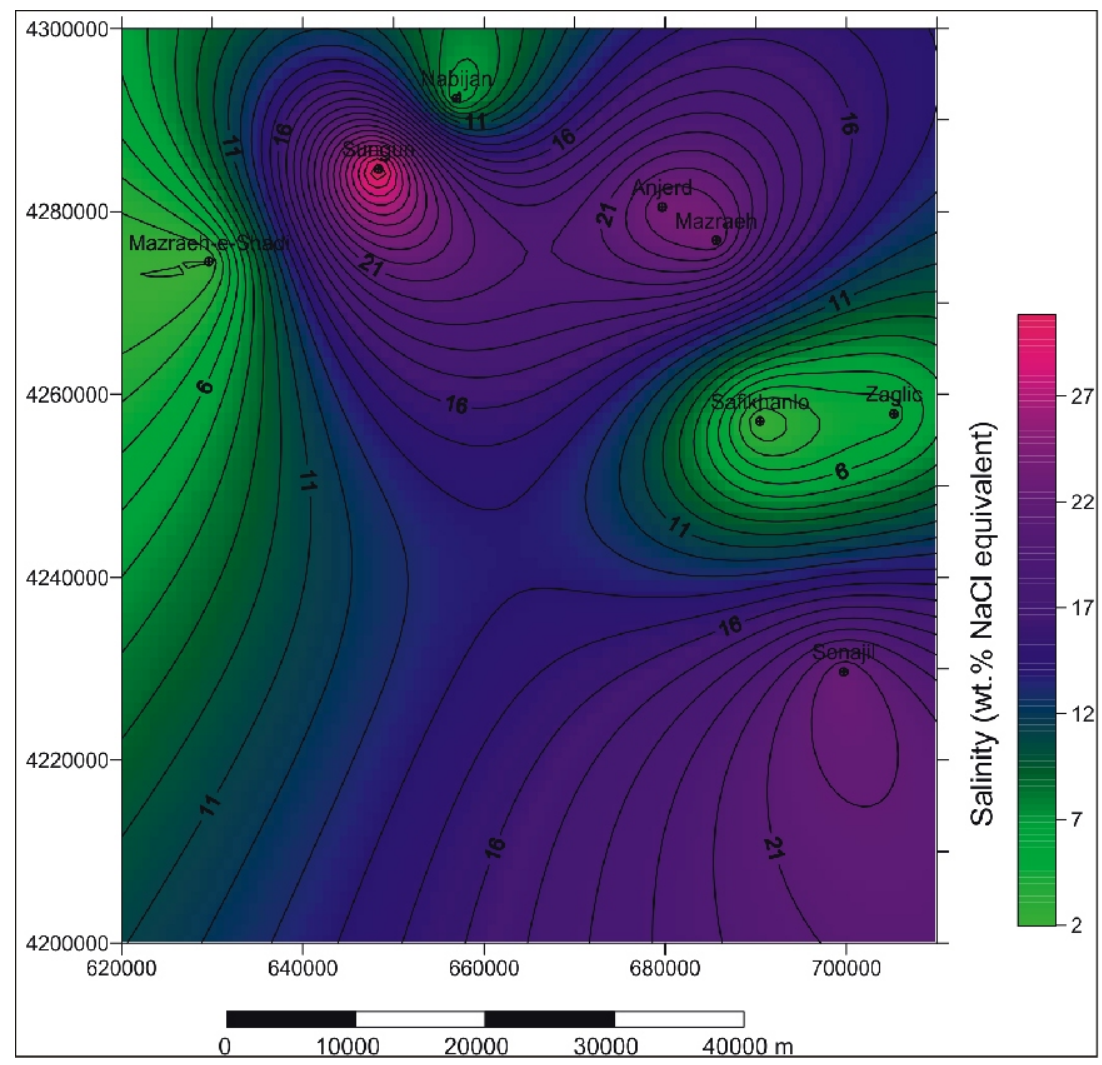

Fig. 20. The salinity (wt. $\% \mathrm{NaCl}$ equivalent) variation 


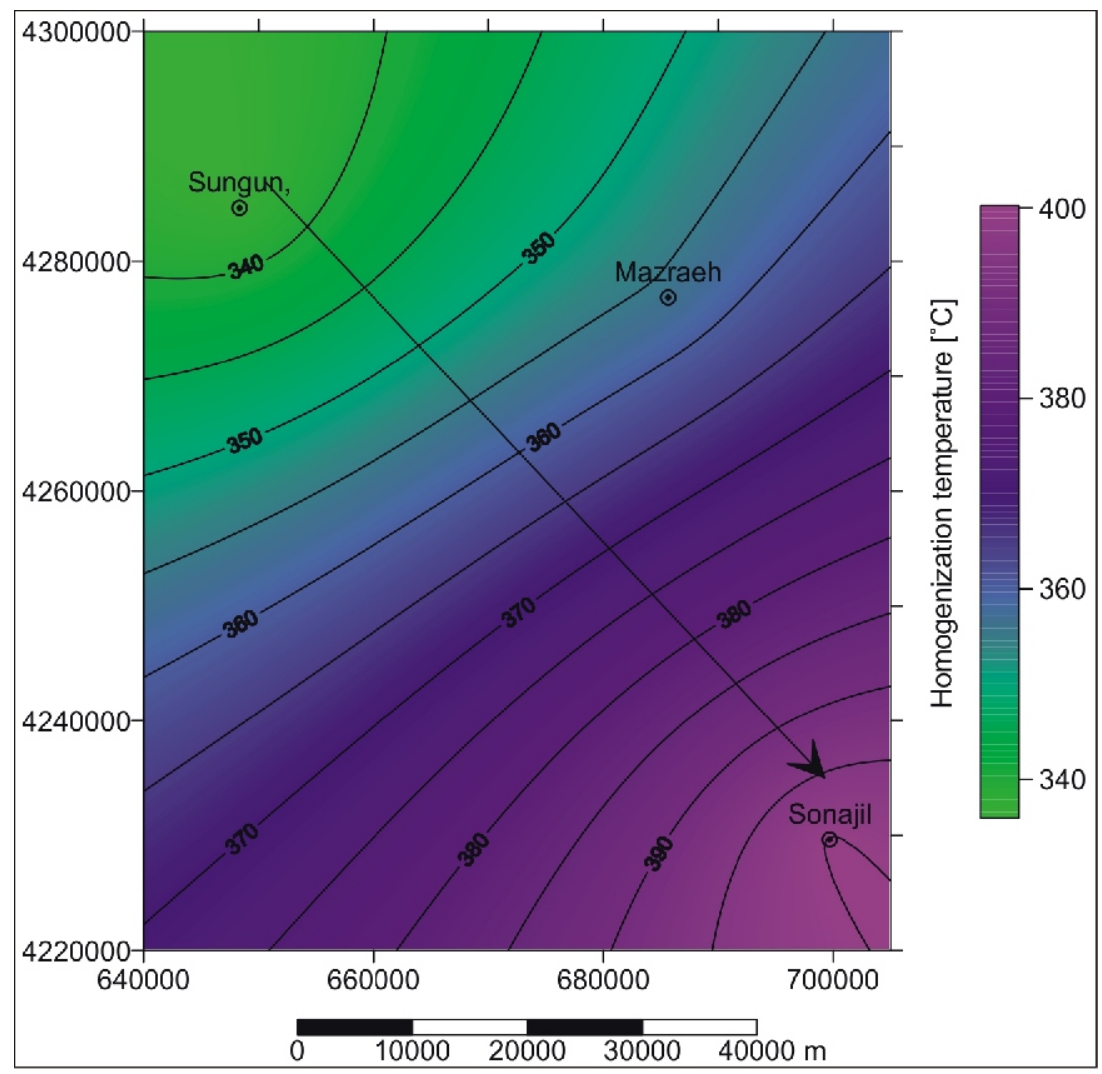

Fig. 21. The homogenization temperature $\left({ }^{\circ} \mathrm{C}\right)$ variation in porphyry and skarn deposits (from Sungun to Sonajil)

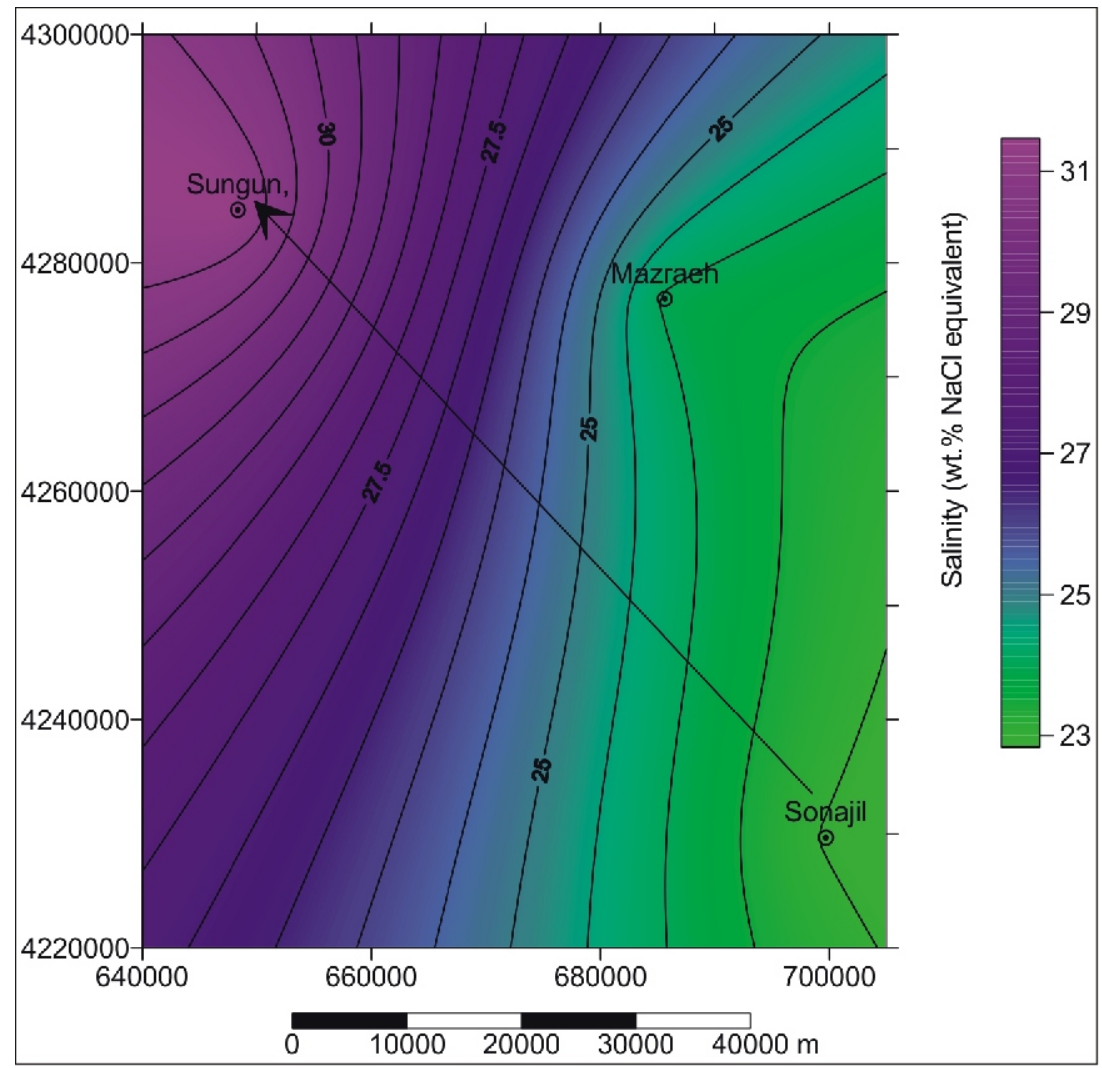

Fig. 22. The salinity (wt. \% $\mathrm{NaCl}$ equivalent) variation in porphyry and skarn deposits (from Sungun to Sonajil) 
he homogenization temperature $\left({ }^{\circ} \mathrm{C}\right)$ zonation and salinity (wt.\% $\mathrm{NaCl}$ equivalent) zoning (Figs. 19 and 20) are recognized from the centres (Sungun, Sonajil and Mazraeh) towards the margins of the mineralizing system (Mazraeh-e-Shadi, Zaglic, Safikhanlo and Valilu). These zonation patterns (Figs. 18-20) indicate that three mineralization centres represented by porphyry and skarn deposits (Sungun, Sonajil and Mazraeh) were formed in this region, surrounded by epithermal deposits. There is a distinctive zonation from Sungun to Sonajil, with marked decrease in salinity (wt.\% $\mathrm{NaCl}$ equivalent) and increase in homogenization temperature $\left({ }^{\circ} \mathrm{C}\right.$; Figs. 21 and 22). Summarizing, the homogenization temperature and salinity decreases from the centre to the outer zone, suggesting that fluids migrated up-dip the central parts of the mineralizing system. Thus, highand low-sulfidation epithermal deposits reflect end-members in a continuum of magmatic-hydrothermal processes that progressively incorporated more non-magmatic waters as the volcanic system wand, or as one moves away from the volcanic centre.

\section{CONCLUSIONS}

Cenozoic rocks of the Arasbaran metallogenic zone compositionally can be classified as subalkaline basalt, andesite/basaltic andesite, and rhyodacite/dacite and they plot mainly in the subalkaline field. Most of the igneous rocks associated with the deposits fall in the volcanic arc granites field, while some of the younger (Miocene) quartz-monzonitic and monzonitic plutons straddle the boundary with, and fall into the field of, intra-plate granites.

Comparison of rare earth element variations across the porphyry and skarn deposits indicates a similarity to epithermal deposits, suggesting a similar source for the REE. The REE ratios reflect fractionations as follows: LREE/HREE > LREE/MREE> MREE/HREE and the highest values of the these ratios have been observed in the Mazraeh-e-Shadi and Nabijan deposits. Accordingly, all of the deposits studied are located in an area between Nabijan and Sonajil and show chiefly alkaline conditions of formation.

Basic conditions of hydrothermal alteration decrease from the epithermal deposits to the porphyry and skarn deposits and from the north to the south and from west to east due to the relationships between these deposits.

Geochemically, these deposits show similar trace element characteristics and overlapping inter-element ratios, indicating common melt sources. Their enrichment in light lithophile element and high incompatible element abundances suggests derivation of their magmas from a subduction-metasomatized, subcontinental lithospheric mantle source.

Fluid inclusion evidence indicates that two types of hydrothermal fluids participated in the formation of all deposits: high and low temperature fluids.

In this region most deposits record a concentric zonation on a regional scale, suggesting that the heat was generated in the centre of the mineralizing system, where the porphyry and skarn deposits were formed (i.e. in the Sungun and Sonajil areas). The relationship between the deposits indicates that the epithermal deposits post-dated the porphyry and skarn mineralization. This is supported by the homogenization temperatures and by salinities recorded in fluid inclusion data, which demonstrate that the fluids migrated up-dip and were spreading towards the margins of the zonation pattern. This is shown by the zonation from Sungun to Sonajil, with marked decreases in salinity and increases in homogenization temperature.

Acknowledgements. The authors are grateful to the research committee of Lorestan University and the University of Tabriz for supporting this project. The authors would like to thank the IMIDRO and the Copper Company for technical support and an anonymous reviewer is thanked for a constructive review and suggestions.

\section{REFERENCES}

Aftabi, A., Atapour, H., 2010. Alteration geochemistry of volcanic rocks around Sarcheshmeh porphyry copper deposit, Rafsanjan, Kerman, Iran: implications for regional exploration. Journal of Resource Geology, 61: 76-90.

Aftabi, A., Taghipour, N., Mathur, R., 2008. Geology and Re-Os geochronology of mineralization of the Meiduk porphyry copper deposit, Iran. Journal of Resource Geology, 58: 143-160.

Aghazadeh, M., Castro, A., Badrzadeh, Z., Vogt, K., 2011. Post-collisional polycyclic plutonism from the Zagros hinterland: the Shaivar Dagh plutonic complex, Alborz Belt, Iran. Geological Magazine, 148: 980-1008.

Aghazadeh, M., Hou, Z., Badrzadeh, Z., Zhou, L., 2015. Temporal-spatial distribution and tectonic setting of porphyry copper deposits in Iran: constraints from zircon U-Pb and molybdenite Re-Os geochronology. Ore Geology Reviews, 70: 385-406.

Akbarpur, A., 2007. Economic geology of the Kiamaki area, eastern Azerbaijan, with spatial view on Cu-Au mineralization in Masjed Daghi (in Persian). Ph.D. thesis, Free University of Iran, Tehran, Iran.

Alavi, M., 1994. Tectonic of the Zagros orogenic belt of Iran: new data and interpretations. Tectonophysics, 22: 211-239.

Alirezaei, S., Ebrahimi, S., Yuanming Pan., 2011. Geological setting, alteration, and fluid inclusion characteristics of Zaglic and
Safikhanlo epithermal gold prospects, NW Iran. Geological Society Special Publications, 350: 133-147.

Alirezaei, S., Einali, M., Jones, P., Hassanpour, Sh. Arjmandzadeh, R., 2016. Mineralogy, geochemistry, and evolution of the Mivehrud skarn and the associated pluton, northwest Iran. International Journal of Earth Sciences, 105: 849-868.

Asiabanha, A., Foden, J., 2012. Post collisional transition from an extensional volcanosedimentary basin to a continental arc in the Alborz Ranges, N-Iran. Lithos, 148: 98-111.

Atalu, S., 2006. Report of detail exploration in Sonajil Cu porphyry occurrence, east of Heris, Eastern Azerbaijan. National Iranian Copper Company ( $\mathrm{NICICO}$ ) (internal report).

Aubert, D., Stille, P., Probst, A., 2001. REE fractionation during granite weathering and removal by waters and suspended loads: $\mathrm{Sr}$ and $\mathrm{Nd}$ isotopic evidence. Geochimica et Cosmochimica Acta, 65: 387-406.

Azizi, H., Jahangiri, H., 2008. Cretaceous subduction-related volcanism in the northern Sanandaj-Sirjan Zone, Iran. Journal of Geodynamics, 45: 178-190.

Azizi, H., Moinevaziri, H., 2009. Review of the tectonic setting of Cretaceous to Quaternary volcanism in northwestern Iran. Journal of Geodynamics, 47: 167-179. 
Bakker, R.J., 1997. Clathrates: computer programs to calculate fluid inclusion $\mathrm{V}-\mathrm{X}$ properties using clathrate melting temperatures. Computers, Geosciences, 23: 1-18.

Bakker, R.J., 1999. Optimal Interpretation of Microthermometrica Data from Fluid Inclusion; Thermodynamic Modelling and Computer Programming. University Heidelberg, Germany.

Baniadam, F., 2002. Study of geology and genesis of Au-Cu mineralization in the Nabijan area. M.Sc. thesis, Faculty of Earth Science, GSI.

Batchelder, J., 1977. Light stable isotope and fluid inclusion study of the porphyry copper deposit at Copper Canyon, Nevada. Economic Geology, 72: 60-70.

Bodnar, R.J., 1993. Revised equation and table for determining the freezing point depression of $\mathrm{H}_{2} \mathrm{O}-\mathrm{NaCl}$ solutions. Geochimica et Cosmochimica Acta, 57: 683-684.

Brooking, D.G., 1984. Geochemical Aspects of Radioactive Waste Disposal. Springer, New York.

Brown, P.E., 1989. Flincor: a microcomputer program for the reduction and investigation of fluid-inclusion data. American Mineralogist, 74: 1390-1393.

Calagari, A.A., 1997. Geochemical, stable isotope, noble gas and fluid inclusion studies of mineralization and alteration at Sungun porphyry copper deposit, East Azerbaijan, Iran: implication for genesis. Ph.D. thesis, Manchester University, Manchester.

Calagari, A.A., 2003. Stable isotope (S, O, H and C) studies of the phyllic and potassic-phyllic alteration zones of the porphyry copper deposit at Sungun, East Azarbaidjan, Iran. Journal of Asian Earth Sciences, 21: 767-780.

Calagari, A.A., Hosseinzadeh, G., 2006. The mineralogy of copper-bearing skarn to the east of the Sungun-Chay River East-Azarbaidjan, Iran. Journal of Asian Earth Sciences, 28 423-438.

Castro, A., Aghazadeh, M., Badrzadeh, Z., Chichorro, M., 2013. Late Eocene-Oligocene postcollisional monzonitic intrusions from the Alborz magmatic belt, NW Iran. An example of monzonite magma generation from a metasomatized mantle source. Lithos, 180-181: 109-127.

Chivas, A.R., Wilkins, W.T., 1977. Fluid inclusion studies in relation to hydrothermal alteration and mineralization at the Koloula porphyry copper prospect, Guadalcanal. Economic Geology, 72 153-169.

Crinci, J., Jurkowic, I., 1990. Rare earth elements in Triassic bauxites of Croatia Yugoslavia. Travaux, 19: 239-248.

Daliran, F., Borg, G., Armstrong, R., Vennemann, T., Walther, J., Woodhead, J.D., 2007. Non sulphide zinc deposits, Iran: The hypogene emplacement and supergene modification history of the Angouran zinc deposit, NW-Iran. Series on the Researches on Ore Deposit and Mineral Resources, Report of The German Federal Institute for Geosciences and Natural Resources (BGR), Hannover.

Dilek, Y., Sandvol, E., 2009. Seismic structure, crustal architecture and tectonic evolution of the Anatolian-African plate boundary and the Cenozoic orogenic belts in the Eastern Mediterranean Region. Geological Society Special Publications, 327: 127-160.

Dilek, Y., Imamverdiyev, N., Altunkaynak, S., 2010. Geochemistry and tectonics of Cenozoic volcanism in the Lesser Caucasus (Azerbaijan) and the peri-Arabian region: collision-induced mantle dynamics and its magmatic fingerprint. International Geology Review, 52: 536-578.

Ebrahimi, S., Alirezaei, S., Pan, Y., 2009. Various epithermal precious metal systems in the Urmieh-Dokhtar magmatic assemblage, Iran. Goldschmidt Conference Abstracts.

Einaudi, M.T., 1982. Description of skarns associated with porphyry copper plutons. In:Advances in Geology of the Porphyry Copper Deposits, Southwestern North America (ed. S.R. Titley): 139-184. University of Arizona Press, Tucson.

Etminan, H., 1977. The discovery of porphyry copper-molybdenum mineralization adjacent to Sungun village in the northwest of Ahar and a proposed program for its detailed exploration. Confidential Report, Geological Report, Geological Survey of Iran.
Frost, B.R., Barnes, C.G., Collins, W.J., Arculus, R.J., Ellis, D.J., Frost, C.D., 2001. A geochemical classification for granitic rocks. Journal of Petrology, 42: 2033-2048.

Ghadimzadeh, H., 2002. Economic geology and exploration for gold in the Safikhanlo-Noghdouz area (SE Ahar). M.Sc. thesis, Faculty of Earth Science, Geological Survey of Iran Tehran, Iran.

Haas, J.L., 1971. The effect of salinity on the maximum thermal gradient of a hydrothermal system at hydrostatic pressure. Economic Geology, 66: 940-946.

Hassanpour, Sh., 2010. Metallogeny and Mineralization of Copper and Gold in Arasbaran Zone (Eastern Azerbaijan) (in Persian with English abstract). Ph.D. thesis, Shahid Beheshti University, Tehran.

Heidarzadeh, R., 2006. Mineralogy, alteration and genesis of gold mineralization in Saglik-Sarikhanlu area. M.Sc. thesis, Faculty of Earth Science, Geological Survey of Iran, Tehran, Iran.

Hezarkhani, A., 2006. Petrology of the intrusive rocks within the Sungun Porphyry Copper Deposit, Azerbaijan, Iran. Journal of Asian Earth Science, 27: 326-340.

Hezarkhani, A., Williams-Jones, A.E., 1998. Controls of alteration and mineralization in the Sungun Porphyry Copper Deposit, Iran: Evidence from fluid inclusions and stable isotopes. Economic Geology, 93: 651-670.

Hosseinzadeh, G., 2008. Geology, geochemistry, fluid inclusions, alteration and genesis of Sonajil porphyry copper deposit, East of Heris, Eastern Azerbaijan. Ph.D. thesis, Tabriz University, Tabriz.

Jamalia, H., Mehrabi, B., 2015. Relationships between arc maturity and $\mathrm{Cu}-\mathrm{Mo}-\mathrm{Au}$ porphyry and related epithermal mineralization at the Cenozoic Arasbaran magmatic belt. Ore Geology Reviews, 65: 487-501.

Jamalia, H., Dilek, Y., Daliranc, F., Yaghubpurd, A., Mehrabid, B., 2010. Metallogeny and tectonic evolution of the Cenozoic Ahar-Arasbaran volcanic belt, northern Iran. International Geology Review, 52: 608-630.

Karadag, M., Kupeli, S., Aryk, A., Ayhan, A., Zedef, V., Doyen, A., 2009. Rare earth elements (REE) geochemistry and genetic implications of the Mortas bauxite deposit (Seydisehir/KonyaSouthern Turkey). Chemie der Erde, 69: 143-159.

Karimpour, M.H., Malekzadeh, A., Nazi, M., 2014. Discrimination of different erosion levels of porphyry Cu deposits using ASTER Image processing in the Maherabad, Shadan Chah shaljami areas. Acta Geologia Sinica, 88: 1195-1213.

Karimzadeh Somarin, A., Moayyed, M., 2002. Granite- and gabrodiorite-associated skarn deposits of NW Iran. Ore Geology Reviews, 20: 127-138.

Kato, Y., 1999. Rare earth elements as an indicator to origins of skarn deposits, example of the Kamioka $\mathrm{Zn}-\mathrm{Pb}$ and Yoshiwara-Sannotake (Cu-Fe) deposit in Japan. Resource Geology, 49: 183-198.

Kikawada, Y., 2001. Experimental studies on the mobility of lanthanides accompanying alteration of andesite by acidic hot spring water. Chemical Geology, 176: 137-149.

Knarchenko, S.M., Pokrovsky, B.G., 1995. The Tomtor alkaline ultrabasic massif and related REE-Nb deposit, Northern Siberia. Economic Geology, 90: 676-689.

Laffitte, P., 1984. Metallogenic map of Europe and adjacent regions, 1:2,500,000 scale and explanatory memoir. UNESCO Earth Sciences Series, 17

Le Maitre, R.W., 2002. Igneous Rocks - A Classification and Glossary of Terms, $2 \mathrm{~d}$ ed., Cambridge University Press.

Maniar, P.D., Piccoli, P.M., 1989. Tectonic discrimination of granitoids. GSA Bulletin, 101: 635-643.

Meinert, L.D., Dipple, G.M., Nicolescu, S., 2005. World skarn deposits. Economic Geology, 100: 299-336

Mitchell, A.H.G., 1996. Distribution and genesis of some epizonal $\mathrm{Zn}-\mathrm{Pb}$ and $\mathrm{Au}$ provinces in the Carpathian-Balkan region: Transactions of the Institution of Mining and Metallurgy, 105: B127-B138. 
Mohajjel, M., Fergusson, C.L., 2000. Dextral transpression in late Cretaceous continental collision, Sanandaj-Sirjan Zone, western Iran. Journal of Structural Geology, 22: 1125-1139.

Mollai, H., 1993. Petrochemistry and genesis of the granodiorite and associated iron-copper skarn deposit of Mazraeh, Ahar, East-Azerbaijan, Iran. Ph.D. thesis, University of Rookee, India.

Mollai, H., Sharma, R., Pe-Piper, G., 2009. Copper mineralization around the Ahar batholith, North of Ahar (NW Iran): evidence for fluid evolution and the origin of the skarn ore deposit. Ore Geology Reviews, 35: 401-414.

Mollai, H., Pe-Piper, G., Dabiri., 2014. Genetic relationships between skarn ore deposits and magmatic activity in the Ahar region, Western Alborz, NW Iran. Geologica Carpathica, 65: 207-225.

Nabatian, G., Jiang, S.Y., Honarmand, M., Neubauer, F., 2016. Zircon U-Pb ages, geochemical and $\mathrm{Sr}-\mathrm{Nd}-\mathrm{Pb}-\mathrm{Hf}$ isotopic constraints on petrogenesis of the Tarom-Olya pluton, Alborz magmatic belt, NW Iran. Lithos, 244: 43-58.

Nabavi, M., 1976. An Introduction to the Geology of Iran (in Persian). Geological Survey of Iran Publication.

Nash, J.T., Theodore, T.G., 1971. Ore fluids in the porphyry copper deposit at Copper Canyon, Nevada. Economic Geology, 66: 385-399.

Nash, J.T., 1976. Fluid inclusion petrology, data from porphyry copper deposits and applications to exploration. United States Geological Survey, Professional Paper, 907-D.

Pearce, J.A., Harris, N.B.W., Tindle, A.G., 1984. Trace element discrimination diagrams for the tectonic interpretation of granitic rocks. Journal of Petrology, 25: 956-983.

Pollard, P.J., 1995. A special issue devoted to the geology of rare metal deposits, geology of rare metal deposits: an introduction and overview. Economic Geology, 90: 489-494.

Purnik, P., 2006. Report of detail exploration for gold in the Sharafabad-Hizejan (Mazraeh-e-Shadi), NW Iran. Internal Report, Geological Survey of Iran.

Radmard, K., Zamanian, H., Hosseinzadehgh, M.R., Ahmadi Khalaji, A., 2017. Geochemistry and hydrothermal evolution of ore deposition at the Mazraeh-e-Shadi-Hizehjan precious and base metal deposit, northeastern Tabriz, Iran. Journal of Mineralogy and Geochemistry, 194: 227-250.

Radmard, K., Zamanian, H., Hosseinzadehgh, M.R., Ahmadi Khalaji, A., 2019. Constraints on ore formation conditions at the Mazra'eh Shadi epithermal deposit, NE Tabriz, Iran: evidences from geochemistry, sulphur isotope, quartz textures and fluid inclusion studies. Geological Quarterly, 63 (2): 230-247.

Rard, J.A., 1988. Aqueous solubility's of praseodymium, europium and lutetium sulfates. Journal of Solution Chemistry, 17: 499-517.

Richards, J.P., 2003. Metallogeny of Neotethys arc in central Iran, 7th Biennial Meeting, Society for Geology Applied to Mineral Deposits; Mineral exploration and sustainable development, Athens: $1237-1240$

Roedder, E., 1984. Fluid inclusions. Reviews in Mineralogy, 12

Rolland, Y., Cox, S., Boullier, A., Pennacchioni, G., 2003. Rare earth and trace element mobility in mid-crustal shear zones: insights from the Mont Blanc Massif (Western Alps). Earth and Planetary Science Letters, 214: 203-219.

Rolland, Y., Billo, S., Corsini, M., Sosson, M., Galoyan, G., 2009. Blueschists of the Amassia-Stepanavan Suture Zone (Arme- nia): linking Tethys subduction history from E-Turkey to W-Iran. International Journal of Earth Sciences, 98: 533-550.

Rollinson, H., 1993. Using Geochemical Data: Evolution, Presentation, Interpretation. Longman, London.

Rose, A.W., Burt, D., 1979. Hydrothermal alteration. In Geochemistry of Hydrothermal Ore Deposits (ed. H.L. Barnes): 173-235. John Wiley and Sons, New York.

Shand, S.J., 1927. Eruptive Rocks. D. Van Nostrand Company, New York.

Shokohi, H., 2007. Report of 1:1000 geological map and drillings in Nabijan area. Internal Report, Geological Survey of Iran.

Sillitoe, R.H., 1997. Characteristics and controls of the largest porphyry copper-gold and epithermal gold deposits in the circum-Pacific region. Australian Journal of Earth Sciences, 44: 373-388.

Simmonds, V., Moazzen, M., 2015. Re-Os dating of molybdenites from Oligocene Cu-Mo-Au mineralized veins in the Qarachilar area, Qaradagh batholith (northwest Iran): implications for understanding Cenozoic mineralization in South Armenia, Nakhchivan and Iran. International Geology Review, 57: 290-304.

Simmonds, V., Moazzen, M., Mathur, R., 2017. Constraining the timing of porphyry mineralization in northwest Iran in relation to Lesser Caucasus and Central Iran; Re-Os age data for Sungun porphyry Cu-Mo deposit. International Geology Review, 59: 1561-1574.

Sosson, M., Rolland, Y., Corcini, M., Danelian, T., Stephan, J.F., Avagyan, A., Melkonian, R., Jrbashian, R., Melikian, L., Galoian, G., 2005. Tectonic evolution of Lesser Caucausus (Armenia) revisited in the light of new structural and stratigraphic results. Geophysical Research Abstracts, 7: 06224.

Taylor, Y., McLennan, S.M., 1985. The Continental Crust: Its Composition and evolution. Blackwell, Oxford.

Wilkinson, J.J., 2001. Fluid inclusion in hydrothermal ore deposits. Lithos, 55: 229-272.

William-Jones, A.E., Heinrich, C.A., 2005. Vapour transport of metals and the formation of magmatic-hydrothermal ore deposits. Economic Geology, 100: 1287-1312.

Wood, S.A., 1990. The aqueous geochemistry of the ra-re-earth elements and Yttrium. Theoretical predic-tions of speciation in hydrothermal solutions to $350^{\circ} \mathrm{C}$ at saturation water vapor pressure. Chemical Geology, 88: 99-125.

Yang, Z., Hou, Z., White, N.C., Chang, Z., Li, Z., Song, Y., 2009 Geology of the post-collisional porphyry copper-molybdenum deposit at Qulong, Tibet. Ore Geology Reviews, 36: 133-159.

Yusoff, Z.M., Ngwenya, B.T., Parsons, I., 2013. Mobility and fractionation or REE during deep weathering of geochemically contrasting granites in a tropical setting, Malaysia. Chemical Geology, 349-350: 71-86.

Zarasvandi, A., Liaghat, S., Zentilli, M, 2005. Geology of the Darreh-Zerreshk and Ali-Abad Porphyry Copper Deposits, Central Iran. International Geology Review, 47: 620-646.

Zarasvandi, A., Rezaei, M., Raith, J., Lentz, D., Azimzadeh, A.-M., Pourkaseb, H., 2015. Geochemistry and fluid characteristics of the Dalli porphyry Cu-Au Deposit, Central Iran. Journal of Asian Earth Sciences, 111: 175-191. 